NBER WORKING PAPER SERIES

\title{
PRICE VARIATION IN MARKETS WITH HOMOGENEOUS GOODS: THE CASE OF MEDIGAP
}

\author{
Nicole Maestas \\ Mathis Schroeder \\ Dana Goldman \\ Working Paper 14679 \\ http://www.nber.org/papers/w14679
NATIONAL BUREAU OF ECONOMIC RESEARCH
1050 Massachusetts Avenue
Cambridge, MA 02138
January 2009

We thank Moshe Buchinsky, Amy Finkelstein, Tom Rice, John Romley, and workshop participants at the NBER Summer Institute, RAND Labor and Health Brown Bag, and Duke/UNC Triangle Health Economics Seminar for helpful comments and suggestions. We are especially grateful to Weiss Ratings, Inc. for generously providing us with Medigap price data. Maestas gratefully acknowledges funding from the NIH Roybal Center for Health Policy Simulation at RAND and the Bing Center at RAND. Corresponding authors: Nicole Maestas, maestas@rand.org and Mathis Schroeder, schroeder@mea.uni-mannheim.de. The views expressed herein are those of the author(s) and do not necessarily reflect the views of the National Bureau of Economic Research.

NBER working papers are circulated for discussion and comment purposes. They have not been peerreviewed or been subject to the review by the NBER Board of Directors that accompanies official NBER publications.

(C) 2009 by Nicole Maestas, Mathis Schroeder, and Dana Goldman. All rights reserved. Short sections of text, not to exceed two paragraphs, may be quoted without explicit permission provided that full credit, including $\odot$ notice, is given to the source. 
Price Variation in Markets with Homogeneous Goods: The Case of Medigap

Nicole Maestas, Mathis Schroeder, and Dana Goldman

NBER Working Paper No. 14679

January 2009

JEL No. I2

\begin{abstract}
$\underline{\text { ABSTRACT }}$
Nearly 30 percent of Americans age 65 and older supplement their Medicare health insurance through the Medigap private insurance market. We show that prices for Medigap policies vary widely, despite the fact that all plans are standardized, and even after controlling for firm heterogeneity. Economic theory suggests that heterogeneous consumer search costs can lead to a non-degenerate price distribution within a market for otherwise homogenous goods. Using a structural model of equilibrium search costs first posed by Carlson and McAfee (1983), we estimate average search costs to be $\$ 72$. We argue that information problems arise from the complexity of the insurance product and lead individuals to rely on insurance agents who do not necessarily guide them to the lowest prices.
\end{abstract}

Nicole Maestas

RAND Corporation

1776 Main Street

P.O. Box 2138

Santa Monica, CA 90407-2138

Nicole_Maestas@rand.org

Mathis Schroeder

Universitat Mannheim

68131 Mannheim

GERMANY

schroeder@mea.uni-mannheim.de

\author{
Dana Goldman \\ RAND Corporation \\ 1776 Main Street \\ P.O. Box 2138 \\ Santa Monica, CA 90407-2138 \\ and NBER \\ dgoldman@rand.org
}




\section{Introduction}

Nearly all Americans age 65 and older obtain basic health insurance coverage through the Medicare program. Although the introduction of Medicare led to a substantial reduction in out-of-pocket expenditure risk (Finkelstein and McKnight, 2005), the elderly still face significant financial risk due to Medicare's large deductibles, co-insurance rates, and caps (Goldman and Maestas, 2005). To help individuals insure against these "gaps" in Medicare coverage, a private individual insurance market for supplemental coverage evolved, known as the Medigap market. In 2004, 29 percent of Medicare beneficiaries held supplemental Medigap insurance policies (MedPac, 2007). As an example of a private insurance market that interfaces with the public Medicare program, the Medigap experience offers useful lessons about the role of information that may be applicable to other private insurance markets that tie-in to the Medicare program, such as Medicare Part D or Medicare Advantage.

Prior to July 1992, the Medigap market was only minimally regulated. Insurance companies were free to offer consumer-specific contracts, varying the extent of coverage from contract to contract and underwriting on the basis of health status as long as minimum benefit standards were met. In 1991, thirteen percent of Medicare beneficiaries held two or more supplemental insurance plans (US General Accounting Office, 1994), which in many cases provided redundant coverage (Short and Vistnes, 1992).

Furthermore, consumers were reportedly confused about their coverage options and at times taken advantage of by insurance companies (US Department of Health and Human Services, 1995).

The Omnibus Budget Reconciliation Act (OBRA) of 1990 introduced regulations intended to strengthen consumer rights and transparency in the Medigap market: ten standardized plans labeled A through $\mathrm{J}$ were established, the purchase and sale of multiple plans was prohibited, and medical underwriting was greatly restricted. Despite these regulations, one characteristic of the market did not change: prices continue to vary substantially between companies offering the same Medigap plans, even though coverage packages are now identical (Weiss Ratings Inc., 1997-2005). In their 10-year review of the market since OBRA 1990, Fox, Snyder and Rice (2003) noted that insurer loss ratios 
have changed little since 1990 and questioned whether price competition in the market has improved.

This paper has two primary aims. First, we document evidence of extensive price variation in all segments of the Medigap market in 2004: in all states, for all policy types, and under all pricing methods. Within local markets, we calculate a plan-weighted coefficient of variation in premiums for the same policy of 0.26 . Applying quantity weights, the coefficient of variation in premiums declines to 0.13 , but remains substantial. ${ }^{1}$ Even after further accounting for potential differences in firm quality-most importantly, the financial strength of the insurance company - price variation of this magnitude persists.

Second, we investigate why price variation persists in the Medigap market. Because of the standardization imposed by OBRA 1990, the Medigap market is in essence a market with homogeneous goods. The existence of price variation in a market with homogeneous goods is an indicator of imperfect information in the market (e.g., see Stiglitz, 1989), and suggests that when consumers buy high-priced Medigap policies instead of identical lower-priced ones, welfare losses occur. To guide our analysis, we apply a theoretical model presented by Carlson and McAfee (1983) that explains the existence of a discrete price distribution in a market for homogenous goods with differences in cost structures across firms and consumers who face heterogeneous search costs. The Carlson-McAfee model has been used to study price variation in a variety of settings. For example, Dahlby and West (1986) found support for the model's main predictions in the market for auto insurance. In a study of local pharmacy markets in upstate New York, Sorensen (2000) found more variation in prices for acute-care medications than for medications used to treat long-term chronic conditions, where the expected gains from searching were larger. Horteçsu and Syverson (2004) applied the Carlson-McAfee model to the market for S\&P 500 index funds, finding that increased market participation by novice investors moved the search cost distribution rightward, leading to higher search costs and thereby supporting the existence of more expensive funds.

\footnotetext{
${ }^{1}$ As a point of comparison, Stigler's (1961) classic article on the economics of information described markets with coefficients of variation in the neighborhood of 0.02 (automobiles) and 0.07 (anthracite coal), much smaller than those described here.
} 
The Medigap market is an ideal setting for studying price variation because Medigap insurance products are unusually well-defined. Importantly, standard Medigap plans do not have a service component; they are only secondary insurance policies, and do not integrate insurance with service delivery. They do not grant or restrict access to particular networks of physicians, hospitals or drug formularies. ${ }^{2}$ In addition, care is not "managed." If Medicare covers a particular service, so does Medigap (up to standardized plan limits), and it is typically not necessary to file a separate claim with the Medigap insurer; rather, Medigap claims are filed directly by the Medicare carrier for physicians that either accept Medicare assignment or have made "automatic crossover" arrangements. As a consequence of these characteristics, quality differences across policies are naturally minimized.

Applying the Carlson-McAfee model to the Medigap market, we estimate a maximum search cost of $\$ 144$, and an average search cost of $\$ 72$. By way of comparison, average search costs ranged from $\$ 28$ to $\$ 132$ in the market for auto insurance (Dahlby and West, 1986), and between $\$ 5$ and $\$ 30$ for every $\$ 10,000$ of assets invested in the mutual fund market (Horteçsu and Syverson, 2004). Our findings suggest that elderly consumers vary in their abilities to identify the best policies in terms of price and other firm characteristics like financial strength. Even though price information is often available on state insurance department websites, and financial ratings are easy to obtain on the internet, older consumers either do not use the internet to access this information, or do not make efficient use of the information once found. We argue that the complexity of the interaction between Medicare and Medigap policies, the extensive (and perhaps overwhelming) array of unique options available, the elevated incidence of cognitive limitations among older individuals, and the high costs associated with fixing "wrong" choices, all lead to a setting in which "choice overload" is likely to prevail. To compensate, individuals turn to others whom they perceive to be experts: insurance agents. As we show, agents sell the vast majority of policies in the market but do not necessarily steer buyers to the best policies.

\footnotetext{
${ }^{2}$ A few companies offer hybrid plans (called "Select" policies), which restrict provider choice to particular networks. We do not include these plans in our analysis. In their 10-year review of the post-OBRA 1990 Medigap market, Fox, Snyder and Rice (2003) note that few Select plans have been sold and that consequently they are not a major factor in the marketplace.
} 


\section{Institutional Background}

Medicare, enacted in 1965, provides health insurance coverage for people 65 and older and for certain disabled individuals. However, coverage is far from complete Medicare only covers basic needs and even then, substantial co-insurance and copayments are required. Medicare coverage has two components: Part A hospital insurance for inpatient and limited nursing home care, and Part B medical insurance for physician services and outpatient procedures. For those who have worked for at least 10 years (or whose spouses have), Part A has no premium and coverage starts automatically at age 65 . Part B coverage requires a monthly premium and active enrollment.

Since the introduction of Medicare, there has been demand for insurance against its out-of-pocket costs. In 2004, 29 percent of Medicare beneficiaries held supplemental insurance through the private Medigap market, another 32 percent held supplemental coverage through their former employer, about 14 percent were enrolled in a Medicare managed care plan, 14 percent received supplemental coverage through the Medicaid program, and nearly 10 percent had no supplemental coverage (MedPac, 2007).

Since its inception, the Medigap market has attracted the concern of policymakers. Allegations of insurer fraud and concerns that the elderly were both uniformed about their coverage needs and unable to navigate the complexities of supplemental coverage offers led Congress to pass legislation defining voluntary minimum standards in 1980, known as the Baucus Amendments. Nearly all states adopted the minimum standards, which set standards for minimum coverage amounts, limited exclusions for pre-existing conditions, required insurers to offer "free look" periods, and set loss ratio requirements (Rice and McCall, 1985; Rice, 1987; Finkelstein, 2004). Nevertheless, concerns about insurer malpractice grew, as consumer protection agencies accused insurers of extracting large rents by intentionally misleading people into purchasing multiple plans with duplicate coverage (Select Committee on Aging, 1990). This led to drastic reforms of the Medigap market with the passage of the Omnibus Budget Reconciliation Act (OBRA) in 1990. The most important reform was the requirement that insurers conform their plan offerings to a set of ten standardized plans, labeled A through J. Table 1 shows the coverage offerings of each of the ten plans. The 
plans range from coverage of only coinsurance (Plan A) to coverage of coinsurance, deductibles, excess charges, foreign travel emergency, at-home recovery, prescription drugs, ${ }^{3}$ and certain preventive care services (Plan J). ${ }^{4}$ Standardization was intended to increase the comparability of plan offers across insurance companies, which would hopefully enhance competition, lead to price reductions, and generate welfare gains for consumers.

A second important reform was the establishment of an open enrollment period during which medical underwriting is prohibited. The open enrollment period runs for six months, beginning when consumers turn 65 and enroll in Medicare Part B. ${ }^{5}$ During open enrollment, an insurance company must accept a consumer's application regardless of medical condition, and can vary premiums only on the basis of age, gender, and smoking status. After the open enrollment period ends, insurers are free to engage in medical underwriting. Other regulations included guaranteed renewability of insurance policies, higher minimum loss ratio requirements ${ }^{6}$, and the prohibition of selling plans with duplicate coverage. These federal regulations came into effect in 1992 in all states but Massachusetts, Minnesota, and Wisconsin, where similar regulatory measures had previously been introduced.

With underwriting limited to age, gender, and smoking status, insurance companies were left with few ways of varying premiums to match risk exposure. In addition to varying premiums by gender and smoking status, they could use three different methods of varying premiums by age: attained age rating, community rating, and issued age rating. Each method represents a different kind of risk pooling within an insurance plan. Attained age plans vary premiums according to the consumer's current

\footnotetext{
${ }^{3}$ Since January 1, 2006, new issuances of Medigap plans H, I, and J no longer include prescription drug coverage. Those who held a Medigap policy with prescription drug coverage had the option of maintaining drug coverage through their Medigap policy or switching to a new Medicare prescription drug plan by May 15,2006 . Those who switched during this window of time also had the right to switch to a different Medigap plan letter offered by their insurer. These changes affected a very small segment of the Medigap market; only 9 percent of Medigap plan enrollees were enrolled in plans H, I, and J in 2001 (Kaiser Family Foundation, 2005).

${ }^{4}$ In 2005, two new lower-cost standardized plans were introduced (Plans K and L), which offer fewer benefits and higher out-of-pocket costs subject to annual limits. We do not include the new plans in our analyses because our data pre-date their introduction.

${ }^{5}$ For example, for a consumer who turned 65 on the $1^{\text {st }}$ of January in 1998, but enrolled in Medicare part B on April $1^{\text {st }}$, the open enrollment period begins on April $1^{\text {st }}$ and ends on September $30^{\text {th }}$.

${ }^{6}$ The loss ratio is defined as the ratio of claims over premiums, reflecting the share of premiums collected from policyholders that is used to cover incurred medical costs.
} 
age, whereas community rated plans pool all risks and charge the same premium to all policyholders regardless of age (although some differentiate by gender). Issued age premiums are based on the consumer's buy-in age, not on her actual age, and therefore the same premium is charged to all individuals who bought at the same age, regardless of the calendar year in which they first bought their policy. If an insurance company wishes to raise premiums, it must do so for all policyholders within the same rating class. For example, it is not possible for an insurer to increase the premium separately for the oldest people in a community rated or issued age plan - this would only be allowed in an attained age plan. Each rating method implies a different age profile in premiums. Attained age plans feature a relatively low premium at age 65 but a steeply rising premium profile with age ${ }^{7}$, whereas issued age plans have higher age 65 premiums and less steeply rising premium profiles with age. ${ }^{8}$ For community rated plans, the age profile is flat. (For a detailed discussion, see Schroeder, Maestas, Goldman, 2005.)

It is important to note that because medical underwriting is permitted after the open enrollment period, individuals who wish to switch Medigap plans could face potentially large premium increases. Hence, the regulations largely deter individuals from voluntarily changing plans, and generally limit market-destabilizing gaming strategies such as buying an attained age plan when young (and premiums are relatively low) and switching to a cheaper community rated plan when older (and attained age premiums are relatively high). ${ }^{9}$

\footnotetext{
${ }^{7}$ The steep premium profile has led 12 states to either ban attained age rating or mandate community rating. These states include Arkansas, Connecticut, Florida, Georgia, Idaho, Maine, Massachusetts, Minnesota, Missouri, New York, Vermont, and Washington (Lutzky et al., 2001 and authors' research to identify recent adopters).

${ }^{8}$ For Plan A, the average annual increase in premiums is about 3 percent for attained age rating in the first ten years, compared to 2.2 percent for issued age plans (Schroeder, Maestas, Goldman, 2005).

${ }^{9}$ The federal regulations offer protection against medical underwriting after the open enrollment period in special situations such as when an individual loses coverage because their Medigap insurer goes bankrupt; an individual voluntarily leaves a Medicare HMO within one year of first enrolling; an individual's Medicare HMO withdraws from their service area or otherwise terminates their coverage; an individual moves out of their Medicare HMO's service area; or a former employer terminates retiree health benefits (Centers for Medicare and Medicaid Services, 2006). In addition, states have the option of going beyond the federal regulations. Currently, Connecticut and New York have "continuous" open enrollment (i.e. no medical underwriting ever permitted), while California, Maine, and Massachusetts have an annual open enrollment period of one month around a person's birthday (The Lewin Group, 2001).
} 


\section{Price Variation}

\subsection{Data}

We draw on two sources of data in our empirical analyses. Our first dataset, from Weiss Ratings, Inc., is a snapshot of Medigap premiums in effect in 2004. The Weiss data capture about 91 percent of all firms operating nationwide, and are voluntarily provided by insurance companies. Firms report their premiums for the Medigap plan letters they offer by gender, age, smoking status, rating method, and zip code. To reduce the dimensionality of our analysis, we focus on policies offered to female nonsmokers at age 65 (the most common buy-in age, and when most people are in their open enrollment period). The data also include the Weiss financial safety rating for each insurance firm, where " $\mathrm{A}$ " is "excellent", " $\mathrm{B}$ " is "good", " $\mathrm{C}$ " is "fair", " $\mathrm{D}$ " is "weak", and "E" and "F" are "very weak" and "failed", respectively. Plusses and minuses are used within each grade to further differentiate firms.

Our second dataset, from the National Association of Insurance Commissioners (NAIC), is an administrative regulatory database containing total premiums, claims, and covered lives for each plan letter offered by an insurance company in every state. Insurance companies are required by law to file with NAIC, thus the NAIC data represent the universe of Medigap policies. In each year of NAIC data, the data are aggregated across policies newly issued during the previous three years. For example, the data for 2004 contain covered lives for new policies issued by a particular firm in a given state in 2002, 2003 and 2004 combined. The number of new covered lives in 2004 will be approximately proportional to new covered lives for 2002-2004 if firms maintained approximately stable market shares over the period.

We merge the NAIC and Weiss data with the goal of creating a dataset that contains price, quantity sold (covered lives), and production costs (claims) for each Medigap plan offered by a firm in every market. However, the two datasets are not strictly comparable and three issues arise when attempting to merge them. We provide an overview of the major issues here, and additional details in Appendix 2. First, as the NAIC data are available at the state level, we must aggregate the Weiss data. As we document in the following section, we do not lose much information in doing so since insurers predominantly vary premiums across states, rather than within states. 
Second, NAIC reports the total number of new policies issued by an insurer in each state for all ages. We assume sales to 65-year olds are a fixed proportion of all sales; a reasonable assumption given that new Medicare entrants dominate the market. Finally, in merging the Weiss and NAIC data, we retain observations for 72 out of 108 firms in the NAIC universe, accounting for 91 percent of total covered lives. As shown in Table 2, the composition of our merged sample is similar to the entire NAIC data set in terms of average loss ratio, the number of firms per state, the distribution of covered lives over plan letters, rating methods, solicitation method (agent v. direct), and the average number of months a policy has been on the market.

\subsection{The Distribution of Prices within Local Markets}

As we showed in Table 1, the ten standard Medigap plans provide different degrees of coverage. These coverage differences will lead to cost differences, which in turn will lead to premium differences; thus, we expect premiums to vary across plan letters. We also expect them to vary within plan letter on those dimensions permitted by law: gender, smoking status, and age. For example, a smoker will pay more for Plan F than a non-smoker, and men will sometimes pay a different premium than women. ${ }^{10}$ Attained age premiums will generally be lower than issued age and community rated premiums at younger ages, but will be higher at older ages. Finally, the local market in which a plan is sold is an important factor distinguishing two otherwise identical policies - a policy sold in Washington DC will be priced differently than one sold in Los Angeles, on account of differences in population health, state regulations, and local market conditions.

To give an example of the variation in posted premiums within a local market, Table 3 highlights a single zip code, listing all price offers for a single policy, Plan F, Attained Age. In Durham, NC 27708, twenty-seven firms offer Plan F to 65-year-old female nonsmokers under attained-age rating. Annual premiums range from a low of $\$ 1,145$ by United Teacher Associates Insurance Company to a high of $\$ 2,311$ with Oxford Life Insurance Company; the maximum price in the market is twice the minimum

\footnotetext{
${ }^{10}$ In practice, insurance companies do not charge very different premiums to men and women: state average premiums for men and women remain within 5 percent of one another for any given plan, age, and rating method, with men sometimes but not always being charged a higher premium.
} 
price. The mean premium is $\$ 1,560$ and the standard deviation is $\$ 301$. These imply a substantial coefficient of variation of 0.19 . Also listed is the financial safety rating of each firm given by Weiss. Although the 27 firms vary substantially in financial strength, in this particular example, there is little apparent correlation between price and financial rating.

Although insurers are free to vary prices across zip codes or counties, the 2004 Weiss data show that most premium variation occurs across rather than within states. Table 4 shows the extent to which firms vary the prices of their policies over zip codes within a state using the 2004 Weiss data. For each policy sold by a firm, we compute the coefficient of variation (CV) of its premiums over all zip codes within a state. Then for each state, we report the median within-firm $\mathrm{CV}$, the $75^{\text {th }}$ percentile $\mathrm{CV}$, and the highest within-firm CV for all policies sold in the state. We also show the fraction of policies that have the same rank in the price distribution at both the zip code and state levels. For example, there are 82 unique firm-policy combinations in Alaska. The median withinfirm price $\mathrm{CV}$ for those 82 policies is 0.00 , as is the $75^{\text {th }}$ percentile. The maximum within-firm price $\mathrm{CV}$ in the state is 0.03 . In other words, virtually every firm in Alaska charges the same premium in every zip code. On the other hand, in California the median within-firm $\mathrm{CV}$ for 153 firm-policy combinations is 0.15 , and the maximum is 0.27 . In nearly all states, the median within-firm CV is close to zero, and there are many states in which the $75^{\text {th }}$ percentile CV is also close to zero.

It is not altogether surprising that firms do not vary premiums much within states. Insurance companies are subject to regulations and reporting requirements that vary by state (e.g., open enrollment or loss ratio requirements), not county or zip code. In addition, the NAIC data suggest that for most firms the number of policyholders per zip code or county is too small for risk pooling in small geographic areas to be advantageous. We set an arbitrary stringent threshold for the maximum within-firm CV in a state of 0.10 , and consider those states with a maximum below 0.10 as having virtually no withinfirm variation in prices; 24 states meet this criteria. In the state-level analyses that follow, we present analyses for the entire sample and for this subset of "good" states.

We next aggregate the price data up to the state-level by averaging the price of every policy over all zip codes within a state to obtain the state average price for each 
policy. If all firms charged the same price in every zip code, the state-level data would be an exact replica of each and every zip code. However, as we saw in Table 4, a few firms do vary prices across zip codes in some states, and therefore we need to ensure that the aggregation process itself does not generate spurious price variation. To examine this, we compare the distribution of prices at the state and zip levels. Because we expect price to vary by policy type (i.e., plan letter and rating method) as well as across local markets, in the zip code data we regress price on fixed effects defined on a policy-zip code level and plot a kernel density of the residuals. By construction, each residual is the deviation in a firm's price from the local market mean price for the policy. We follow a similar procedure for the state data: we regress the state average price for a policy on fixed effects defined on a policy-state level. Figure 1 shows that the two densities overlap one another nearly perfectly, implying that the aggregated state-level price distribution is an excellent replica of the underlying zip-code level price distribution.

Overlap in the price distributions does not guarantee that every firm occupies the same rank in the state price distribution as in the zip-code distribution. In Table 3, we include a column tabulating the fraction of policies in a state whose price has the same rank at the state level as at the zip level. In about one-fifth of states, all policies occupy the same rank at both the zip and state levels. Among the rest, most policies occupy the same rank at both levels, but there is more evidence of rank differences. This is mostly due to the fact that in some states, a few firms do not operate in all zip codes and thus there are more firms represented at the state level than in some zip codes. For the most part, our designation of "good" states on the basis of the maximum within-firm CV also identifies those states in which nearly all policies occupy the same rank in both price distributions.

Figure 1 is striking in that it shows a substantial amount of price variation within local markets for the same policy; indeed, the distribution has a coefficient of variation of 0.26. ${ }^{11} 12$ While the density of within-market residuals is a useful device for

\footnotetext{
${ }^{11}$ Since the distribution of residuals has mean zero, the CV is computed from the constant, standard error, and number of observations in the regression.

${ }^{12}$ The coefficients of variation reported here for the Medigap market are comparable to those noted in other studies of price dispersion in markets for homogeneous goods. For example, Sorensen (2000) reports an average CV of 0.22 in retail prescription drug markets (page 838), and Dahlby and West (1986) report examples of 0.0739 and 0.1796 (bottom of page 424) for the automobile insurance industry.
} 
summarizing the price variation over many markets and products, we also show the coefficients of variation for the top 10 policies by state, which account for 71 percent of total covered lives. These data are presented in Table 5. The columns are rank ordered, with column 1 representing the largest policy, denoted "F AA" for Plan F, Attained Age. Empty cells indicate that either the policy is not sold in that state, or only one firm offers the policy. Five of the policies are sold in most states, while the other five are sold in just a few states. These tend to be state-mandated guaranteed-issue versions (e.g., denoted " $F$ $\mathrm{AA}^{*}$ ") of the major policies that must be made available to everyone, not just those in their open enrollment period. The table documents substantial price variation throughout the market—within all plan letters, rating methods, and states.

The densities in Figure 1 and underlying Table 5 are plan-weighted, in the sense that each policy gets equal weight regardless of whether any consumers actually buy the policy. If some firms post prices but are not active in the market, then the variation in price could be due to "stale" prices for plans with no enrollees. To examine this, we merge our state-aggregated Weiss data with the regulatory data from NAIC listing covered lives for each policy offered by a firm in every state. Figure 2 shows the (statelevel) distributions of plan-weighted versus quantity-weighted prices. The densities of residual prices are obtained in the same way as for the state-level density in Figure 1. Figure 2 shows that the distribution tightens and shifts rightward once we apply quantityweights, but substantial within-market variation in price remains. The coefficient of variation for the quantity-weighted price distribution is 0.13 . The rightward shift in the distribution reflects the down weighting of stale price offers (which tend to be lower because they have not been recently updated) associated with relatively inactive plans that attract few new buyers.

Price variation could also persist if ostensibly homogeneous products are in fact differentiated on some quality dimension that is observable to consumers, but not to the researcher. Examples of product differentiation might include financial stability of the insurance firm, or firm name recognition. While quality is typically unobserved in many studies of equilibrium price variation, our data include the Weiss financial rating for the firm. As described earlier, the Weiss Safety Rating consists of a letter grade, ranging from $\mathrm{A}+$ to $\mathrm{F}$, and is similar to ratings of financial strength given by other firms such as 
Standard and Poor's. We construct a proxy for name recognition by computing the number of states nationwide in which the firm operates. Other measures include the policy's market tenure, the number of other Medigap policies offered by the firm (i.e., menu size), and whether the policy is sold through agents or directly from the company.

We also control for the within-firm coefficient of variation in the loss ratio computed over all policies the firm offers. Within-firm variation in the loss ratio is an important control if firms cross-subsidize policies by allowing for losses on one (or more) of them, and subsidizing the losses with profits made on other policies. For example, a firm could offer Plan A very cheaply (i.e. below cost) in order to attract people to the company. Then the firm could present the other plans it offers, which (by definition) are better plans in terms of coverage and thus are more expensive. If the premiums for these plans were above costs, the firm could offset losses on Plan A (and perhaps make profits) if enough consumers decided to buy the more expensive plan. If only some firms engaged in this kind of pricing, or if all did but to different extents, prices could vary. ${ }^{13}$ In fact, Table 2 presented indirect evidence of cross-subsidization behavior within firms: in the bottom panel, we show that 9.4 percent of policies have loss ratios above unity, but when we aggregate over all policies within a firm (top panel) we find that just 1.4 percent of firms had loss ratios above unity.

Firms could also cross-subsidize across insurance markets by operating in the Medigap market with losses, but subsidizing these losses with profits from an entirely different insurance market, say long term care or life insurance. However, this seems a less likely explanation for the price dispersion we document since very few firms operate with losses in the Medigap market and the few that do have extremely low market shares (if we re-compute the fraction of firms with a loss ratio above unity using quantity weights, the fraction drops to virtually zero).

Figure 3 shows the quantity-weighted distribution before and after we control for firm quality. The distributions are quite similar, suggesting that little of the price

\footnotetext{
${ }^{13}$ There are limits to the extent to which firms can engage in such behavior. Federal Medigap regulations require insurers to maintain loss ratios (the ratio of claims to premiums) of at least 65 percent for individual plans, and 75 percent for group plans. If that ratio is not met, the insurer has to pay transfers to policyholders. If, as is usually assumed, the administrative costs for Medigap policies are about 10-15 percent of total costs (CMS, 2006b), there remains a maximum profit margin of 25 percent for collected premiums.
} 
variation is due to product differentiation on quality dimensions or loss leader pricing within the Medigap policies.

An important reason for equilibrium price dispersion that has received much attention in the literature is the possibility that firms differ in their costs of production, and these differences are sustained by the existence of consumer search costs. We turn to a discussion of consumer search costs next.

\section{Theoretical Framework}

Several theoretical papers have investigated the implications of incompletely informed consumers who have to gather information before they buy a product. Even with a large number of consumers and sellers, and no heterogeneity in production costs, Diamond (1971) concludes that the monopoly price prevails if there are search costs. Stiglitz (1989) shows how price dispersion arises through cost differentials in the presence of search costs, assuming that consumers are either fully informed or not at all informed (i.e., no learning about the market through sequential search) and a continuous distribution of prices. Carlson and McAfee (1983) relax these particular assumptions. They allow consumers to learn about the market through sequential search, and they assume a discrete price distribution, the latter feature being particularly relevant in the Medigap setting where there are relatively few firms operating in a given market. Perhaps most importantly, their model can be easily manipulated and yields testable predictions. We explain their model and our augmentations in detail in the next section.

\subsection{A Model of Search Costs and Price Dispersion}

Carlson and McAfee (1983) explain sustained price variation in a homogeneous goods market with consumer search costs and variation in production costs. The centerpiece of the model is the presence of incomplete information in the sense that consumers are not fully informed: while they know the price distribution they do not know which firm offers which price. ${ }^{14}$ However, consumers can obtain information about firm-price pairs at a certain cost that is specific to the consumer. Heterogeneity in

\footnotetext{
${ }^{14}$ Virtually all papers in the search cost literature assume a commonly known price distribution. This is necessary to evaluate any consumer's expected (monetary) gain from searching. Otherwise it is not possible for a consumer to assess when to stop searching (in dynamic programming models).
} 
search costs leads to differences in the amount of information obtained, which allows for a non-degenerate price distribution to exist in the market. The model is an equilibrium model, in which both producers and consumers behave optimally given the information constraints they face.

Suppose all consumers gain utility $u_{j}$ if they buy a Medigap policy from firm $j$ :

$$
u_{j}=\lambda X_{j}-p_{j}
$$

where $X_{j}$ is a vector of firm $j$ 's characteristics other than price, $p_{j}$ (e.g., financial stability). Utility is linear and normalized in terms of price. Although the consumer does not know which firms yield which level of utility, she can rank all possible utilities from highest to lowest, $u_{1} \geq u_{2} \geq \ldots \geq u_{N}$. If only prices mattered $(\lambda=0)$ this would correspond to an ordering from lowest to highest price as in Carlson and MacAfee (1983). Here we augment their model to allow factors other than price to affect a firm's ranking. Upon entering the market, the consumer searches once, drawing an offer from firm $k$, which she learns yields utility $u_{k}$. Because she knows the ranking of all $u_{j}$, the consumer can calculate the expected gain, $w_{k}$, from searching again. The expected gain also depends on the probability of a firm being found, where for simplicity (and following Carlson and MacAfee) we assume here that all firms $N$ in a market are found with equal probability $1 / N$. Then, for any utility $u_{k}$, the expected gain is:

$$
w_{k}=\sum_{i=1}^{k-1} \frac{1}{N}\left(u_{i}-u_{k}\right)=\frac{1}{N} \sum_{i=1}^{k-1} u_{i}-\frac{k-1}{N} u_{k}
$$

The consumer then compares the expected gain to her search cost to determine whether to buy this policy or to search for another one. ${ }^{15}$ Each consumer has a search cost $s$, drawn from a cumulative distribution function $G(s)$, where $g(s)=G^{\prime}(s)$. The problem of search then becomes an optimal stopping problem: as long as $s$ is lower than (or equal to) the expected gain, $w_{k}$, the individual will continue to search and stop if and only if $w_{k} \leq s \leq$ $w_{k+1}$. Since the distribution of expected gains is the same for all consumers, the search

\footnotetext{
${ }^{15}$ Search in Carlson and McAfee's model occurs with replacement, i.e. the utility distribution does not change with the number of searches conducted. While this may seem unrealistic, note that consumers are not limited in the number of times they search, but only by their cost of searching again as it compares to their expected gain. They can discard any draw from the utility distribution with lower utility than a previous draw at no cost.
} 
cost distribution, $G(s)$, maps the searching individuals into groups of people that are associated with each firm's utility rank.

Figure 4 (slightly altered from Carlson-McAfee) depicts how the expected gains are distributed in an arbitrary example with five firms and gains from searching $w_{1}<w_{2}<$ $w_{3}<w_{4}<w_{5}$, where $w_{1}=0$. Search costs are distributed uniformly on $[0, S]$, and in this example, the maximum search cost is larger than the maximum possible gain, $w_{5} . W_{5}$ (or $\left[S-w_{5}\right] / S$ ) then depicts the fraction of people in the market that buys the first plan they find. Since all firms are equally likely to be found, $1 / N$ of this group with $s>w_{5}$ buy the plan offering the least utility. $W_{5}$ is also equivalent to the fraction of people that remains uninformed about all other firm-price combinations in the market, except for the one they acquire initially. Similarly, where $W_{l}$ depicts the fraction of people who will always buy at the lowest price, since their search costs are lower than the smallest gain, $w_{2}$. If the maximum search cost is less than the maximum possible gain, $w_{5}$, then the firm offering the least utility will have no buyers, and presumably exits the market (or lowers its price).

To determine the relative demand for each firm's plan in the case of a general price distribution, we start by considering $q_{N}$, the number of individuals that buys at the firm providing the least utility, $u_{N}$. These are all people with search cost $s \geq w_{N}$, who are unlucky enough to draw this firm when entering the market:

$$
q_{N}=\frac{1}{N} G\left(s \geq w_{N}\right)=\frac{1}{N}\left[G(\infty)-G\left(w_{N}\right)\right],
$$

where $G(\infty)=Q$, the total number of individuals in the market. Similarly, we can find the number of individuals that buys at the firm yielding the second lowest utility, firm $N-1$ :

$$
\begin{aligned}
q_{N-1} & =\frac{1}{N} G\left(s \geq w_{N}\right)+\frac{1}{N-1} G\left(w_{N} \geq s \geq w_{N-1}\right) \\
& =\frac{1}{N}\left[G(\infty)-G\left(w_{N}\right)\right]+\frac{1}{N-1}\left[G\left(w_{N}\right)-G\left(w_{N-1}\right)\right]
\end{aligned}
$$

Intuitively, firm $N-1$ attracts $1 / N$ of the consumers with the highest search costs and $1 /(N-$ 1) of those with the second highest search costs. In general, we can obtain each firm $j$ 's demand as:

$$
q_{j}=\sum_{k=j}^{N} \frac{1}{k}\left[G\left(w_{k+1}\right)-G\left(w_{k}\right)\right]=\frac{Q}{N}-\frac{G\left(w_{j}\right)}{j}+\sum_{k=j+1}^{N} \frac{G\left(w_{k}\right)}{k(k-1)},
$$


with $G\left(w_{N+1}\right)=Q$. Equations (2) and (3) can then be used to calculate the number of all consumers in any firm $j$ based on the expected utility gain $w_{j}$ of further search associated with the firm, where we assume in line with Carlson-McAfee that the search cost distribution is uniform on an interval $[0, S]$. This leads to

$$
q_{j}=\frac{Q}{N}-\frac{Q}{j} \frac{w_{j}}{S}+\sum_{k=j+1}^{N}\left[\frac{Q}{k(k-1)} \frac{w_{k}}{S}\right] .
$$

Substituting equation (2) into ( 3 ') yields a demand equation in terms of the utilities associated with each firm $j$ (see Appendix A.1.a. for derivation):

$$
q_{j}=\frac{Q}{N}\left[1-\frac{1}{S}\left(\bar{u}-u_{j}\right)\right],
$$

where, as before, $q_{j}$ depicts the number of consumers in firm $j$. The demand thus depends on the difference in utility derived from firm $j$ 's offer and the market average utility derived from this plan. When the utility gained from firm $j$ 's plan offer increases, firm $j$ 's market demand rises, as

$$
\frac{\partial q_{j}}{\partial u_{j}}=\frac{Q}{N} \frac{1}{S} .
$$

Similarly, firm j's demand also depends on the parameters of the search cost distribution, here defined by the maximum search cost:

(6) $\frac{\partial q_{j}}{\partial S}=\frac{Q}{N} \frac{1}{S^{2}}\left(\bar{u}-u_{j}\right)$.

Thus an increase in the maximum search cost leads to a loss in demand for firms with above average plan utility, and demand gains for firms with below average utility. Hence an upward shift in search costs will lead to a reduction in the variance in market demands, and as $S \rightarrow \infty$ each firm's market demand approaches the average demand, $Q / N$. (In a situation where $S \rightarrow 0$, the search cost distribution is degenerate and every consumer will buy at the firm(s) providing the largest utility, leading to the full information market outcome.) Note also that a reduction in firm $j$ 's demand can be brought about by an increase in the number of firms $(N)$ as well as by an increase in the utility provided by any other firm, as this increases the average market utility.

Carlson and McAfee assume firms are heterogeneous in terms of their (quadratic) cost functions, which are also a function of the search cost distribution: 


$$
c_{j}\left(q_{j}\right)=\alpha_{j} q_{j}+\beta q_{j}^{2}=\alpha_{j}\left\{\frac{Q}{N}\left[1-\frac{1}{S}\left(\bar{u}-u_{j}\right)\right]\right\}+\beta\left\{\frac{Q}{N}\left[1-\frac{1}{S}\left(\bar{u}-u_{j}\right)\right]\right\}^{2},
$$

where $\alpha_{j}>0$ and $\beta \geq 0$. Satisfaction of the condition on $\beta$ guarantees profit maximization. ${ }^{16}$ The profit function is

$$
\Pi_{j}=p_{j} q_{j}-c_{j}\left(q_{j}\right)
$$

and maximizing it with respect to price yields a system of $N$ equations in $N$ unknowns, which can be solved for each price $p_{j}$ (see Appendix A.1.b. for the derivation):

$$
p_{j}=\alpha_{j}+\frac{(1+\gamma) N}{N-1} S+\frac{(1+\gamma) N}{2 N-1+\gamma N}\left(\bar{\alpha}-\alpha_{j}\right)-\frac{(1+\gamma) N}{2 N-1+\gamma N} \lambda\left(\bar{X}-X_{j}\right),
$$

where

$$
\gamma=\frac{2 \beta Q(N-1)}{S N^{2}}
$$

Since only $\alpha_{j}$, and $X_{j}$ vary across firms, variation in $p_{j}$ is determined by firm-specific costs and other characteristics of the firm from which consumers derive utility.

The key feature of the augmented Carlson-MacAfee model is that equilibrium demand, costs, and prices depend on the parameters of the search cost distribution, which is in essence a measure of consumer heterogeneity. Beyond a literal interpretation of search costs as the cost of time and materials employed in search, search costs might measure costs arising from the mental effort applied to the task of acquiring and processing information, or more broadly, could be re-interpreted as a latent distribution of consumer tastes over combinations of firm pecuniary and non-pecuniary characteristics. If the distribution of consumer heterogeneity (whether cast as tastes or time/cognition costs) is correlated with health status then the Carlson-MacAfee model offers an equilibrium model of heterogeneous consumer sorting across insurance firms on an index correlated with health status. Because the parameters of the search cost distribution determine costs and prices, the sorting of consumers into firms can itself generate the cross-firm variation in costs (in this case claims) that drive the equilibrium model. If those in worse health (i.e., with higher expected costs) plausibly have higher search costs, an interesting implication is that the firm offering the least utility will have fewer low risk

\footnotetext{
${ }^{16}$ Note that the derivation in appendix A.1.c. shows that $\beta$ is bounded from below by a values that could be less than zero. However, if $\beta$ is estimated to be positive, firms will meet the profit maximization condition.
} 
policyholders, since low-risk types will search until they find a firm offering higher utility. This will in turn cause prices to be higher at the firm offering the least utility, creating a degree of adverse selection. At the other extreme, the firm offering the highest utility will attract the lowest risk policyholders (as well as a share of the higher risk policyholders). This positive selection will tend to reinforce the firm's position as the offeror of the lowest price/highest utility and its relatively larger market share. Although selection pressures may vary across firms according to their position in the utility distribution, it is important to note that all firms draw a share of the highest risk policyholders (equal to the firm's probability of being found); thus under this interpretation search costs will tend to spread the highest risks across all firms in the market, alleviating selection pressures in any given firm. ${ }^{17}$

\section{Empirical Analyses}

\subsection{Analysis of Firm Costs}

We begin by examining an important determinant of price, namely marginal costs. A key empirical prediction of the Carlson-MacAfee model is that marginal costs vary across firms. Our measure of firm costs is the dollar amount of claims incurred by the insurance firm. While claims are just one component of costs, they are the major variable cost that firms face, and they vary across markets. Dividing total claims by covered lives gives the average cost associated with each policy in every market. Although the empirical prediction in Carlson-MacAfee is with respect to marginal costs, under constant returns to scale (a plausible assumption for this market), marginal costs equal average costs. We regress claims per covered life on policy-state fixed effects (weighting by covered lives) and plot the density of residuals in Figure 5. Each residual represents the deviation in claims per person from the market-level mean of claims per person for a given policy in a given market. The density has substantial spread, indicating a large amount of variation in average costs across firms for the same policy within the same markets. Indeed, the implied coefficient of variation for average costs is 0.33 . Compared to the coefficient of variation in prices reported above (0.13), there is

\footnotetext{
${ }^{17}$ Recent evidence finds that the Medigap market overall experiences positive selection (Fang, Keane and Silverman, 2008).
} 
substantially greater within-market variation in average costs than in prices; the correlation in the within-market coefficients of variation for prices and average costs computed over all markets is 0.25 , pointing to a prominent but not exclusive role for claims in driving price dispersion.

Although the Medigap plan letters refer to a standardized set of insurance benefits, a firm's cost of delivering that set of benefits will depend on several factors, including the local supply of medical services and the efficiency with which it administers the insurance benefit. Supply factors can explain, for example, why Plan F is more expensive in California than Tennessee, but it does not explain why there is substantial variation in costs within a health care market. Our analysis of average claims suggests that the average health of plan enrollees varies from firm to firm. These average health differences could result from differences in marketing strategies (e.g., creamskimming), random variation in health that does not "average out" in smaller plans, or as described above, they could be the result of equilibrium sorting by heterogeneous consumers on a factor correlated with health status.

A second important component of price is the load, or one minus the ratio of expected present discounted insurance benefits to expected present discounted payments. In our data we have neither expected benefit nor payment streams by age; however, we can calculate the loss ratio, claims (expected benefits) divided premiums at age 65 . Combining this fact with knowledge about the structure of risk pooling under the different rating methods makes the age-65 loss ratios for attained age plans, which risk pool within age groups, a useful indicator of loads in the Medigap market. ${ }^{18}$ We regress the loss ratio for each policy on policy-state fixed effects (quantity-weighted) and plot the kernel density of the residuals in Figure 6. As before, each residual measures the deviation from the market mean loss ratio for each policy. The figure shows substantial variation in the loss ratio across firms $(\mathrm{CV}=0.17)$. The mean loss ratio in the market for Attained Age plans is 0.72, which if interpreted as an approximate indicator of the load suggests that the loads on Medigap policies in 2004 are substantial, on average 28 cents

\footnotetext{
${ }^{18}$ This exercise is more difficult with community-rated plans: because policyholders of all ages are part of the same risk pool, premiums are effectively front loaded, exceeding expected claims at younger ages but lower than expected claims at older ages. Thus loss ratios for community-rated policies would tend to bias up the estimate of load. Under attained age rating, premiums are lowest at age 65 and rise with age to match the age profile in claims.
} 
on the dollar. Although this estimate of load pertains to just age 65, given the very high cost of switching policies in the Medigap market it is unlikely that firms would reduce the loads charged on Attained Age plans at older ages.

Because within-market variation in average costs is affected by equilibrium sorting of heterogeneous consumers into different plans, part of the variance in load may reflect sorting, not firm cost structures or profit objectives. The correlation in the withinmarket coefficients of variation in load (one minus the loss ratio) and average costs computed over all markets is -0.55 . Thus, within-market variation in average costs are a central component of the within-market variation in loads, but clearly variation in administrative costs and profit objectives matter as well.

In sum, our analyses of costs and loads suggest patterns consistent with the Carlson-McAfee framework. Average costs for the same policy in the same market vary significantly across firms, as do administrative costs and profit objectives. Given a high average load of 28 cents on the dollar (well in excess of CMS's (2006b) estimate of typical administrative costs of 10-15 percent) firms appear to be profit maximizers. We next turn to the question of why price variation is sustained in the market.

\subsection{Analysis of Demand}

The starting point for our demand analysis is equation (4). Dividing both sides of (4) by $Q_{s p} / N_{s p}$ and adding a stochastic error term $\mu_{j s p}$, yields our empirical specification of the demand equation, where $j$ indexes firms, $s$ indexes states, and $p$ indexes policies (policies are in turn identified by combinations of plan letter, rating method, and whether always guaranteed issue):

$$
\frac{q_{j s p}}{Q_{s p} / N_{s p}}=1-\frac{1}{S}\left(p_{j s p}-\bar{p}_{s p}\right)+\frac{\lambda}{S}\left(X_{j s p}-\bar{X}_{s p}\right)+\mu_{j s p}
$$

The vector $X_{j s p}$ contains our measures of product differentiation. We estimate (4') using a tobit model, since 10 percent of firms in our data report zero covered lives. Note that because the mean of our normalized dependent variable is 1, this specification is equivalent to a fully mean-deviated model. 
In this equilibrium model price is an endogenous variable, itself both determined by and a determinant of demand. To remove variation in prices induced by contemporaneous demand shocks, we instrument for 2004 prices with lagged prices from $2001 .{ }^{19}$ We select the three-year lag because NAIC covered lives for new policies issued $\left(q_{j s p}\right)$ are reported for the interval 2002-2004.

Since all variables are expressed as deviations from the market mean for policy $p$ in state $s$, unobserved market factors are differenced out; however, unobserved firm factors could yet matter. Although we control for a number of important firm characteristics (e.g., financial stability, market presence, market tenure, loss-leader pricing, solicitation method), we have no data measuring firm-specific factors like advertising expenditures. All else equal, a firm that spends more on advertising could have higher demand, as well as higher costs. In this example, our estimated price coefficient would be biased upward. Since the maximum search cost is just the inverse of the price coefficient, our search cost estimate would be biased downward. Even still, to the extent advertising expenditures vary by market, they will be differenced out by the mean deviations. Nonetheless, we make use of a highly relevant and unusually complete set of product differentiation measures, more than are typically available in studies of price variation. Reassuringly, we saw earlier that accounting for observable product differentiation did not appreciably reduce the magnitude of the price variation in the market; therefore it is unlikely that the relationship between price and demand could be entirely explained by additional unobserved factors.

Table 6 presents our estimation results. Column 1 gives the estimated coefficients from a simple tobit specification of the demand equation, and columns 2 and 3 present coefficients for demand and price equations, from the IV tobit specification. In the tobit model, the price coefficient is -0.002 , which implies that for every $\$ 10$ increase in price above the market's average price, a firm's demand decreases by 2 percent of average market demand. Once we instrument with lagged price, the coefficient rises significantly to -0.007 , implying a decrease of 7 percent of average demand for a $\$ 10$ increase in price above average. The estimated maximum search cost, $S$, is the inverse of the price

\footnotetext{
${ }^{19} \mathrm{We}$ also considered using the price a firm charges for a given policy in other states, but the evidence of cross-subsidization within firms indicates that demand shocks experienced by a firm in one state probably affect its prices in other states.
} 
coefficient multiplied by (-1). In the tobit model, we obtain a maximum search cost of $\$ 551$; once we address the simultaneity problem, the maximum search cost declines to about $\$ 144$. Under the assumption that search costs are uniformly distributed, dividing by 2 yields an average search cost of $\$ 72$. The increased responsiveness of consumer demand to variation in relative prices in the IV tobit model makes sense; demand shocks will tend to generate a positive correlation between contemporaneous prices and demand, obscuring the true underlying negative relationship and implying that market rigidities are greater than they actually are.

The sample size declines between the two specifications because some state-firmpolicy combinations in our 2004 sample do not appear in the 2001 Weiss data (they either did not sell the policy in 2001 or did not report to Weiss). ${ }^{20}$ To make sure our estimates are not driven by differences in sample composition, we re-estimate the single-equation tobit model on the subsample used for the IV tobit. The result is shown in Table 7 (column 2), along with additional robustness checks. The price coefficient of -0.002 in the IV subsample is not statistically different from that obtained for the full sample $(t=1.6)$.

In the IV tobit specification in Table 6, many of the product differentiation terms are statistically significant. For example, policies sold by firms with a financial safety rating of A experience notably higher demand than other firms, and policies sold by firms that operate in more states have above average demand. Stale prices (effective date prior to 2003) are associated with lower demand, as are newer policies. Unprofitable policies (loss ratio $>1$ ) and loss leader pricing across policies (as measured by the extent of withinfirm variation in the loss ratio over policies) are associated with lower demand. Demand is higher for policies sold by agents.

In the price equation, the coefficient on lagged price is 0.864 and is highly significant, indicating a very strong first stage $(t=26.8)$. The other coefficients indicate large, positive price differentials associated with financial strength (though the relationship is not monotonic), and using agents as the solicitation method. Prices are lowest for new entrants, suggesting that new entrants attempt to attract market share with

\footnotetext{
${ }^{20}$ The apparent 31 percent reduction in the number of policies corresponds to only a 21 percent reduction in covered lives.
} 
below average prices. This is an important control, since this effect is consistent with market dynamics in the presence of switching costs; the high costs associated with switching insurers may enable firms to charge low initial prices then raise prices later to make up for early age-65 losses. Also of interest is that varying premiums over zip codes within a state is associated with a higher state average premium; this suggests that some firms are able to accomplish and benefit from risk pooling on a smaller scale, trading off higher prices against market share.

Finally, Table 7 presents alternative specifications of the demand equation. Of note is that the price coefficient is identical when we restrict our sample to the "good states." The price coefficient rises to -.009 when we remove all control variables from the IV tobit model; this suggests that accounting for product differentiation increases our estimate of search costs in the Medigap market.

Our estimated average search cost is comparable to those estimated for other markets. For example, using a similar approach, Dahlby and West (1986) found average search costs to be between $\$ 28$ and $\$ 132$ in different segments of the market for auto insurance. Using a somewhat different approach, Hortaçsu and Syverson (2004) found that search costs ranged between $\$ 5$ and $\$ 30$ for every $\$ 10,000$ of assets invested in the mutual fund market. One important difference between this paper and ours is that Hortaçsu and Syverson relax the assumption that firms are found by consumers with equal probabilities. This is perhaps of greater necessity in their application than in ours since they do not have firm characteristics in their data. Our variables measuring market presence, tenure, financial stability, and solicitation method will capture differences in the probabilities of finding a given firm, to the extent they exist. As we discuss in the next section, the availability of consumer pricing guides suggests that the equalprobabilities assumption may be reasonable for this market.

\section{Discussion and Conclusion}

In this paper we investigate why price variation is sustained in the Medigap market for Medicare supplemental health insurance, despite the fact that federal regulations passed in 1992 created standardized insurance products and prohibit insurers from underwriting on the basis of individual health status. Using price data from Weiss 
Ratings and demand data from the National Association of Insurance Commissioners, we analyze the Medigap market in 2004. We show that price variation is substantial, and exists in virtually all segments of the market nationwide. To guide our analysis, we use a theoretical model of equilibrium price dispersion posed by Carlson and McAfee (1983), which we augment to account for firm and product differentiation. We find evidence that the behavior of firms in this market is consistent with the empirical predictions of the Carlson-McAfee model: firms have heterogeneous cost structures and charge high loading fees both of which contribute to price differences. These price differences are sustained in equilibrium by the presence of heterogeneous consumers who vary in their abilities to identify the best policies in terms of price and other firm characteristics, such as financial strength. We estimate the average search cost to be $\$ 72$.

Our results suggest that consumer welfare could be improved if individuals had complete knowledge of the joint distributions of prices and other characteristics of firms in the market. A puzzling aspect of this implication is the fact that price information is widely available on state insurance department websites, firm financial ratings can be easily obtained on the internet as well, and for more than 10 years, Weiss Ratings sold a customized (by age and gender) report listing the prices of all Medigap policies offered in a consumer's zip code along with Weiss' financial safety rating for the insurance firm. The report, known as the "Weiss Ratings Shopper's Guide to Medicare Supplemental Insurance," was marketed and sold via the internet for \$49 in 2004, but was discontinued in 2007. In other words, a significant amount of information is available, but Medigap shoppers are either not finding it or are not making efficient use of it. One barrier to finding it could be the documented low rates of internet access among older people: just 34 percent of households age 65 and older had internet access in 2003 compared to 68 percent of households ages 45-54 (U.S. Census Bureau, 2005). The age disparity in internet use by potential buyers might explain why the internet has reduced price dispersion in other markets, such as life insurance (Brown and Goolsbee, 2002), while significant price dispersion persists in the Medigap market. It also suggests that we should see declines in these search costs in the future given the increases in computer literacy among successive entering cohorts. 
Another interpretation of our results is that while it might not be difficult to find information about the price distribution, it might be difficult to understand how to make efficient use of the information once found. With 10 plans available under 3 different age-rating methods, prospective buyers must choose among as many as 30 different options offered by many different insurers; in fact, depending on their state of residence, individuals face choice sets containing anywhere between 38 to 260 different Medigap policies, or an average of 159 unique options. Recent work in experimental psychology has presented compelling evidence of "choice overload," in which people are demotivated by large choice sets, rendered unsure of the optimal choice and burdened by the sheer difficulty of choosing (Iyengar and Lepper, 2000; Iyengar, Jiang and Huberman, 2003).

Given the relatively advanced age of the consumer population buying Medigap plans, and the potential for age-related cognitive decline among many of them, selecting a Medigap policy is undoubtedly a challenging task for many. Even in the absence of cognitive decline, the Medigap market is quite complicated, and its relationship with the equally complicated Medicare program could be challenging for some to understand. It could also be difficult to understand one's specific needs for supplemental insurance coverage without having had much practical experience with Medicare's coinsurance requirements. A complicating factor is that no individual has any familiarity with the Medigap market prior to turning age 65, and neither do one's adult children, should their assistance be sought. Individuals have a relatively short window of time during which to search for and select a Medigap policy, and the one-shot nature of the market means that learning does not occur with successive purchases. An unfortunate consequence of the one-time open enrollment regulations designed to prevent adverse selection is that mistakes are not easily reversible. Iyengar, Jiang and Huberman (2003) hypothesize that choice overload may be exacerbated in settings in which the costs of making the "wrong" choice are high and the time and effort required to make an informed choice are substantial.

In this context, our results seem plausible given the complex nature of the market and its elderly consumer population. We are by no means the first to argue that the complexity of Medicare and its associated programs could hinder economic efficiency 
and reduce the welfare of the elderly; Rice (1987) called for simplification of the Medicare benefit structure more than two decades ago, and Hibbard et al. (2001), in presenting their estimate that more than half of the Medicare population has difficulty making use of comparative health plan information, argue that "less is more." In fact, the enduring complexity of the Medigap program might explain why even the dramatic reforms resulting in standardization did not fully resolve information problems in the market and enhance competition.

Faced with too many options and no clear criteria for evaluating the options, agents may play a particularly important role in guiding individuals to particular policies. Indeed, 72 percent of Medigap policies are sold through agents. Iyengar, Jiang and Huberman (2003) argue that choice overload leads to situations in which individuals are more likely to surrender choice to someone else; someone they perceive as an expert in the matter at hand. We estimate that agent-solicited policies are about $\$ 140$ more expensive on average than direct-sold policies; thus agents do not guide older individuals to the lowest prices in the market or the most financially sound insurance firms. The present discounted value of the additional premiums paid over the life of the policy greatly exceeds the estimated cost of search.

As policymakers continue to grant the elderly expanded choice in other areas of the Medicare program, such as the Medicare prescription drug program or the Medicare Advantage program, consumer information issues, cognition and the cost of search are especially salient in assessing consumer welfare under the new policies. The experience of the Medigap market is perhaps a cautionary tale; if significant information problems persist even when standardization exists to help consumers navigate the market, they could be even more severe in complex markets without standardization. 


\section{References}

Brown, Jeffrey R., and Austan Goolsbee. 2002. "Does the Internet Make Markets More Competitive? Evidence from the Life Insurance Industry." Journal of Political Economy, Vol. 110, No. 3.

Card, David, Carlos Dobkin and Nicole Maestas. 2008. "The Impact of Nearly Universal Insurance Coverage on Health Care Utilization: Evidence from Medicare." The American Economic Review, forthcoming.

Centers for Medicare and Medicaid Services (CMS). 2006a. "2006 Choosing a Medigap Policy: A Guide to Health Insurance for People with Medicare."

Centers for Medicare and Medicaid Services (CMS). 2006b. "National Health Expenditure Web Tables, Table 12." Downloaded May 2006 at http://www.cms.hhs.gov/NationalHealthExpendData/downloads/tables.pdf.

Carlson, John A., and R. Preston McAfee. 1983. "Discrete Equilibrium Price Dispersion." The Journal of Political Economy, Vol. 91, No 3, pp 480-493.

Dahlby, Bev, and Douglas S. West. 1986. "Price Dispersion in an Automobile Insurance Market." The Journal of Political Economy, Vol. 94, No. 2, pp 418-438.

Diamond, Peter A. 1971. "A Model of Price Adjustment." Journal of Economic Theory, Vol. 3, No. 2, pp 156-168.

Fang, Hanming, et al., Michael P. Keane, and Dan Silverman. 2008. "Sources of Advantageous Selection: Evidence from the Medigap Insurance Market." Journal of Political Economy, Vol. 116, No. 2.

Finkelstein, Amy. 2004. "Minimum Standards, Insurance Regulation and Adverse Selection: Evidence from the Medigap Market." Journal of Public Economics, Vol. 88, No. 12: 2515-47.

Finkelstein, Amy and Robin McKnight. 2005. "What Did Medicare Do (And Was It Worth It)?” NBER Working Paper No. 11609, September 2005.

Fox, Peter D., Rani E. Snyder, and Thomas Rice. 2003. "Medigap Reform Legislation of 1990: A 10-Year Review." Health Care Financing Review, Vol. 24, No. 3, Spring 2003.

Goldman, Dana and Nicole Maestas. 2005. "Medical Expenditure Risk and Household Portfolio Choice.” NBER Working Paper No. W11818. Available at SSRN: http://ssrn.com/abstract $=875694$ 
Hibbard, JH, P Slovic, E Peters, ML Finucane, and M Tusler. 2001. "Is The InformedChoice Policy Approach Appropriate For Medicare Beneficiaries?" Health Affairs, Vol. 20, No. 3, pp. 199.

Hortaçsu, Ali, and Chad Syverson. 2004. "Product Differentiation, Search Costs, and Competition in the Mutual Fund Industry: A Case Study of S\&P 500 Index Funds." The Quarterly Journal of Economics, Vol. 119, No. 2, pp 403-456.

Iyengar, SS and MR Lepper. 2000. "When Choice is Demotivating: Can One Desire Too Much of a Good Thing?" Journal of Personality and Social Psychology, Vol. 79, No. 6, pp. 995-1006.

Iyengar, SS, W Jiang, and G Huberman. 2004. "How Much Choice is Too Much? Contributions to 401 (k) Retirement Plans," in Pension Design and Structure: New Lessons from Behavioral Finance, Oxford University Press, pp. 83-96.

Kaiser Family Foundation. 2005. "Medicare Chart Book.” Section 3, pp. 19-30.

Medicare Payment Advisory Commission (MedPac). 2007. "A Data Book: Healthcare Spending and the Medicare Program, June 2007," p. 61.

Rice, Thomas. 1987. "An Economic Assessment of Healthcare Coverage for the Elderly.” The Milbank Quarterly, Vol. 65, No. 4.

Rice, Thomas and Nelda McCall. 1985. "The Extent of Ownership and the Characteristics of Medicare Supplemental Policies.” Inquiry, 22: 188-200.

Schroeder, Mathis, Nicole Maestas and Dana Goldman. 2005. "Sources of Price Variation in the Medigap Market.” Working paper.

Schroeder, Mathis. 2006. "Premium Variation in the Medigap Market." Cornell University.

Sorensen, Alan T. 2000. "Equilibrium Price Dispersion in Retail Markets for Prescription Drugs." The Journal of Political Economy, Vol. 108, No. 4, pp 833-850.

Short, Pamela Farley, and Jessica Primoff Vistnes. 1992. "Multiple Sources of Medicare Supplementary Insurance.” Inquiry, Vol. 29, pp 33-43.

Stigler, George J. 1961. "The Economics of Information." The Journal of Political Economy, Vol. 69, No. 3.

Stiglitz, Joseph E. 1989. "Imperfect Information in the Product Market." In Handbook of Industrial Organization, Vol. 1, Schmalensee, R. and R.D. Willig, editors. 
The Lewin Group. 2001. "Restricting Underwriting and Premium Rating Practices in the Medigap Market: The Experience of Three States." The Public Policy Institute, report No 2001-01. AARP, Washington, DC.

US Census Bureau, 2005. "Table 2B. Presence of a Computer and the Internet at Home for People 18 Years and Over, by Selected Characteristics: October 2003" Accessed June 2006 at http://www.census.gov/population/socdemo/computer/2003/tab02B.xls.

US Congress, Select Committee on Aging, Subcommittee on Human Services. 1990. "Medigap Fraud and Abuse: How Can Communities Stop These Problems?" Briefing by the Subcommittee on Human Services. Washington, DC, US Government Printing Office.

US General Accounting Office. 1994. "Health Insurance for the Elderly. Owning Duplicate Policies is Costly and Unnecessary”. GAO/HEHS-94-185.

US Department of Health and Human Services. 1995. "The Impact of OBRA 1990 on State Regulation of Medigap Insurance." OEI-09-93-00230.

Weiss Ratings Inc. 1997-2005. "Medigap Insurance News Releases.” Accessed December 2005 at http://www.weissratings.com/News/Ins_Medigap/ . 
Figure 1. Comparison of Within-Market Price Distribution at State and Zip Levels

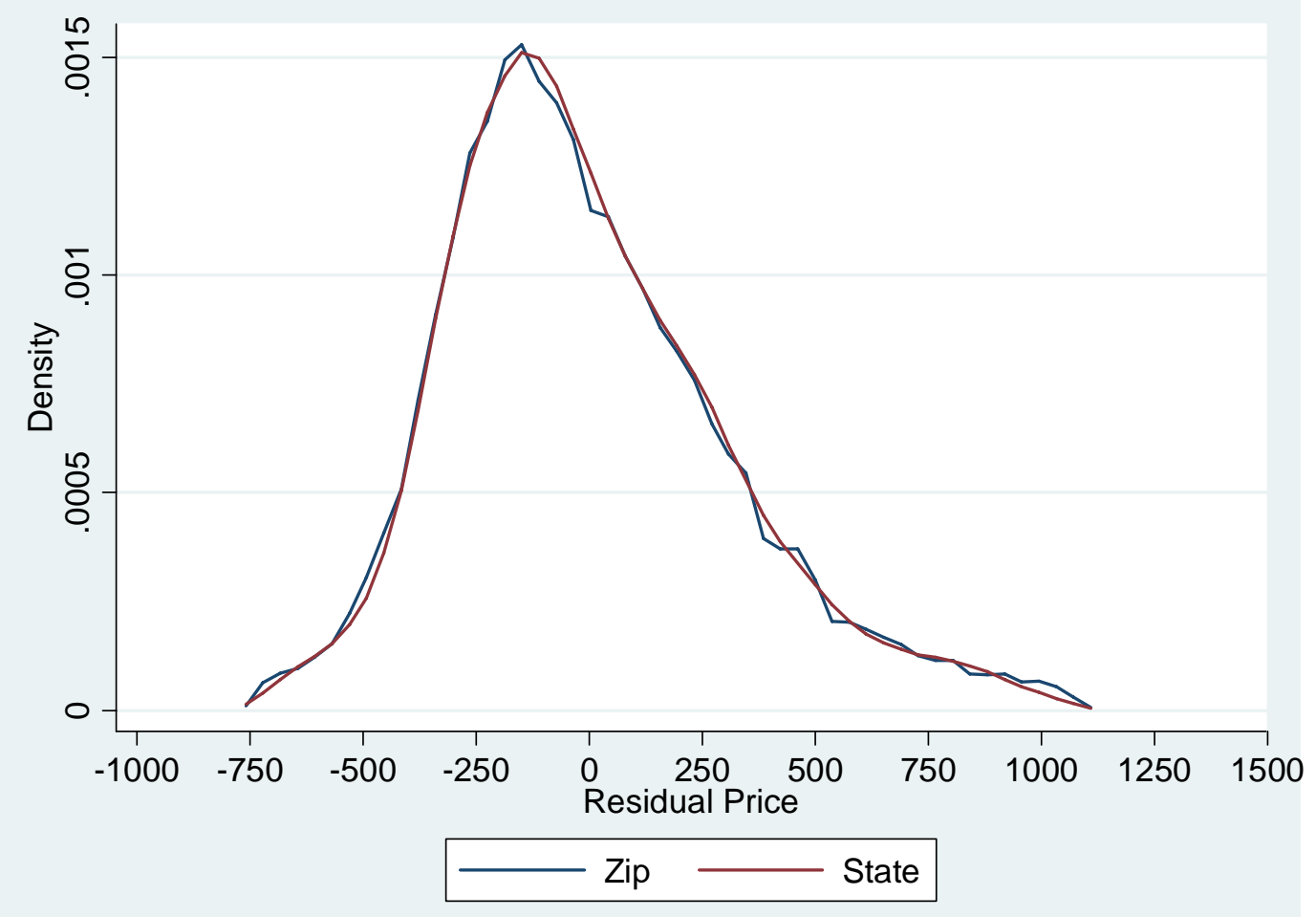

Notes: Price data from Weiss Ratings, Inc., 2004. The zip-code curve is the density of residuals from a regression of premium on policy-zip code fixed effects. The state curve is the density of residuals from a regression of premium on policy-state fixed effects. Shown are $1^{\text {st }}-99^{\text {th }}$ percentiles of each distribution. 
Figure 2. Price Distribution, Plan-Weighted v. Quantity-Weighted

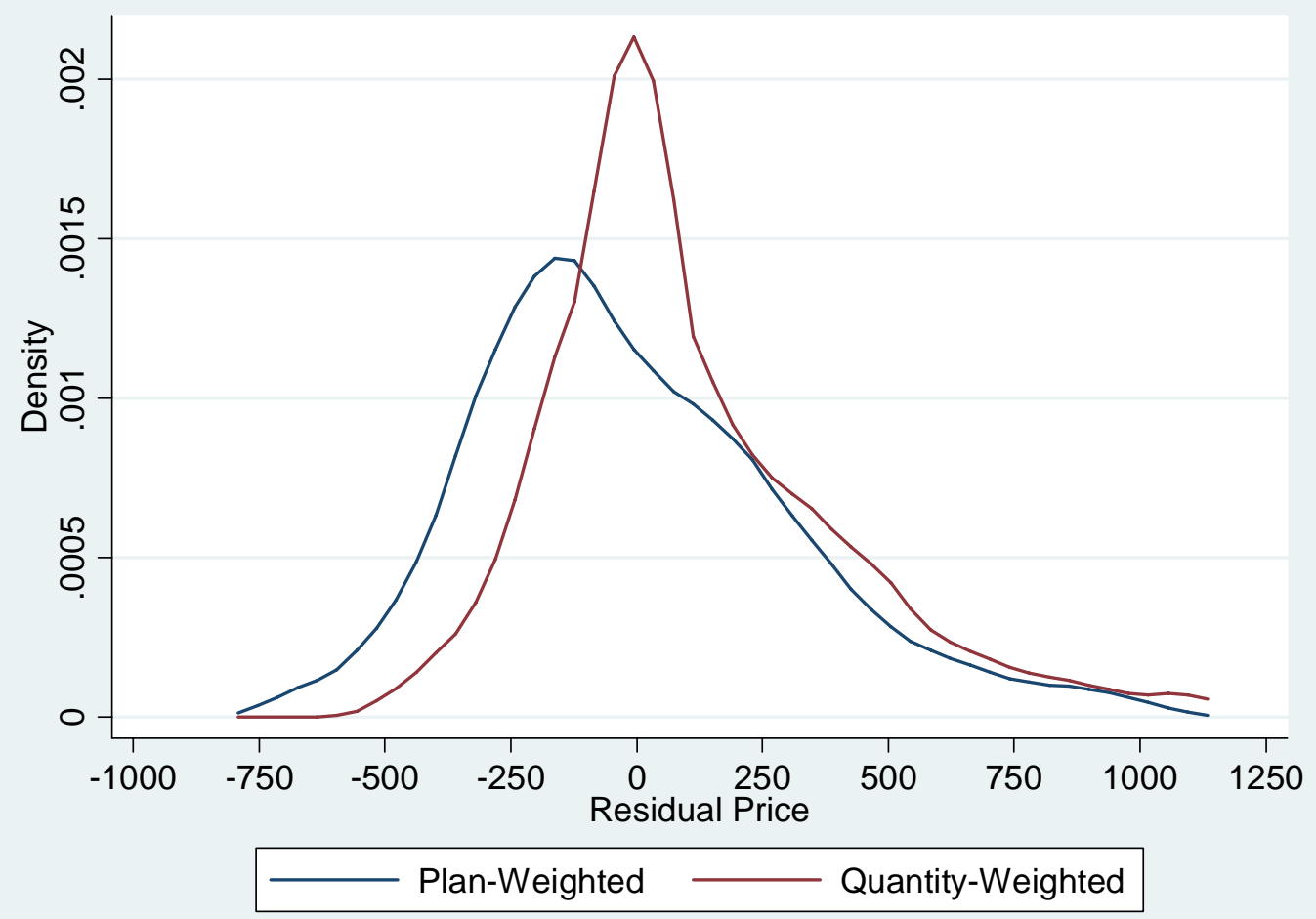

Notes: Price data are from Weiss Ratings, Inc., 2004 and data on covered lives are from National Association of Insurance Commissioners, 2004. Plan-weighted curve is the density of residuals from a regression of premium on policystate fixed effects. Quantity-weighted curve is density of residuals from covered-lives weighted regression of premium on policy-state fixed effects. Shown are 1st-99th percentiles of each distribution. 
Figure 3. Quantity-Weighted Price Distribution, with and without Firm Quality Controls

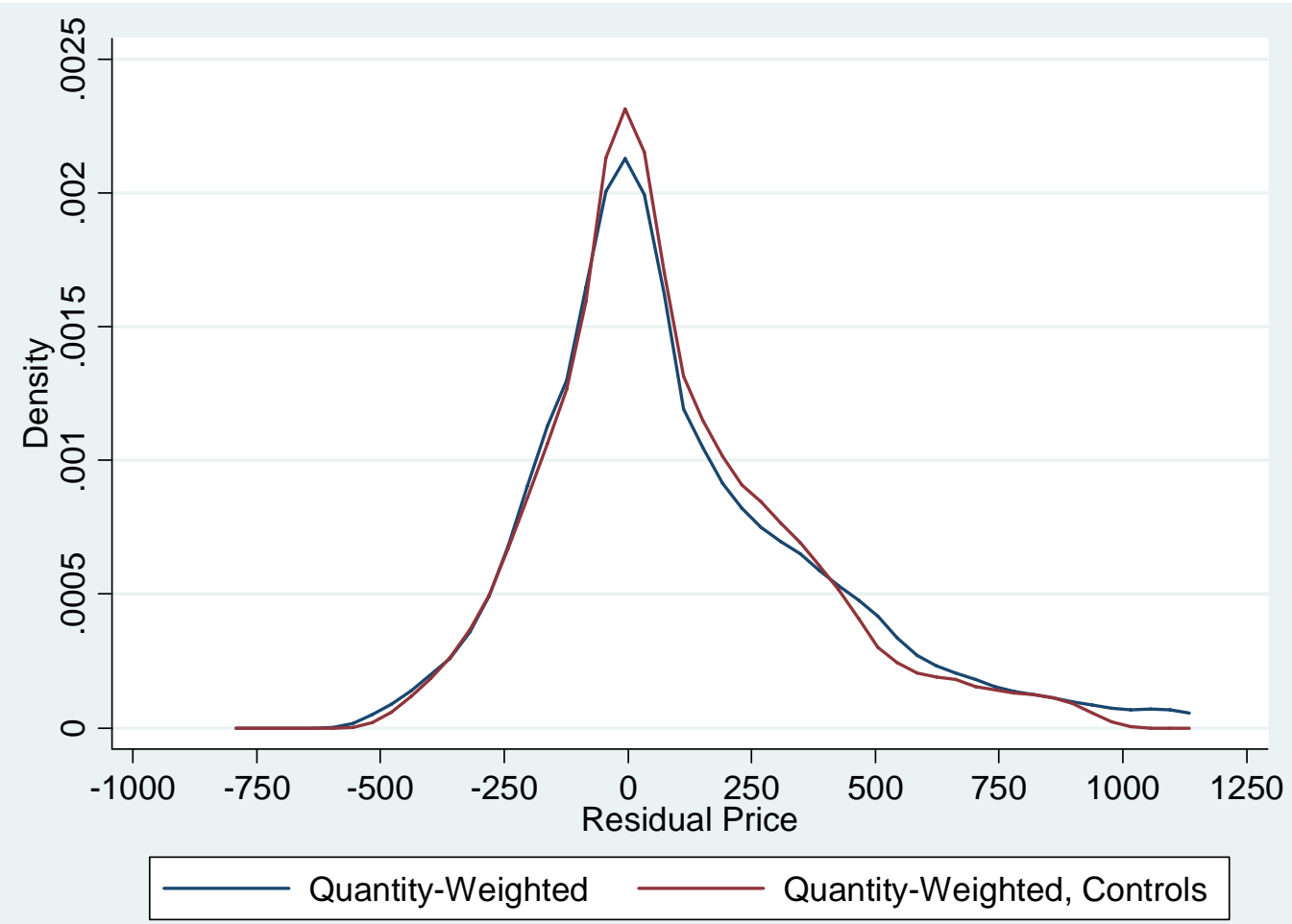

Notes: Price data are from Weiss Ratings, Inc., 2004 and data on covered lives are from National Association of Insurance Commissioners, 2004. Quantity-weighted curves are density of residuals from covered-lives weighted regression of premium on policy-state fixed effects and firm quality controls (see text). Shown are 1st-99th percentiles of each distribution. 
Figure 4: Example of Search Cost and Information Distribution

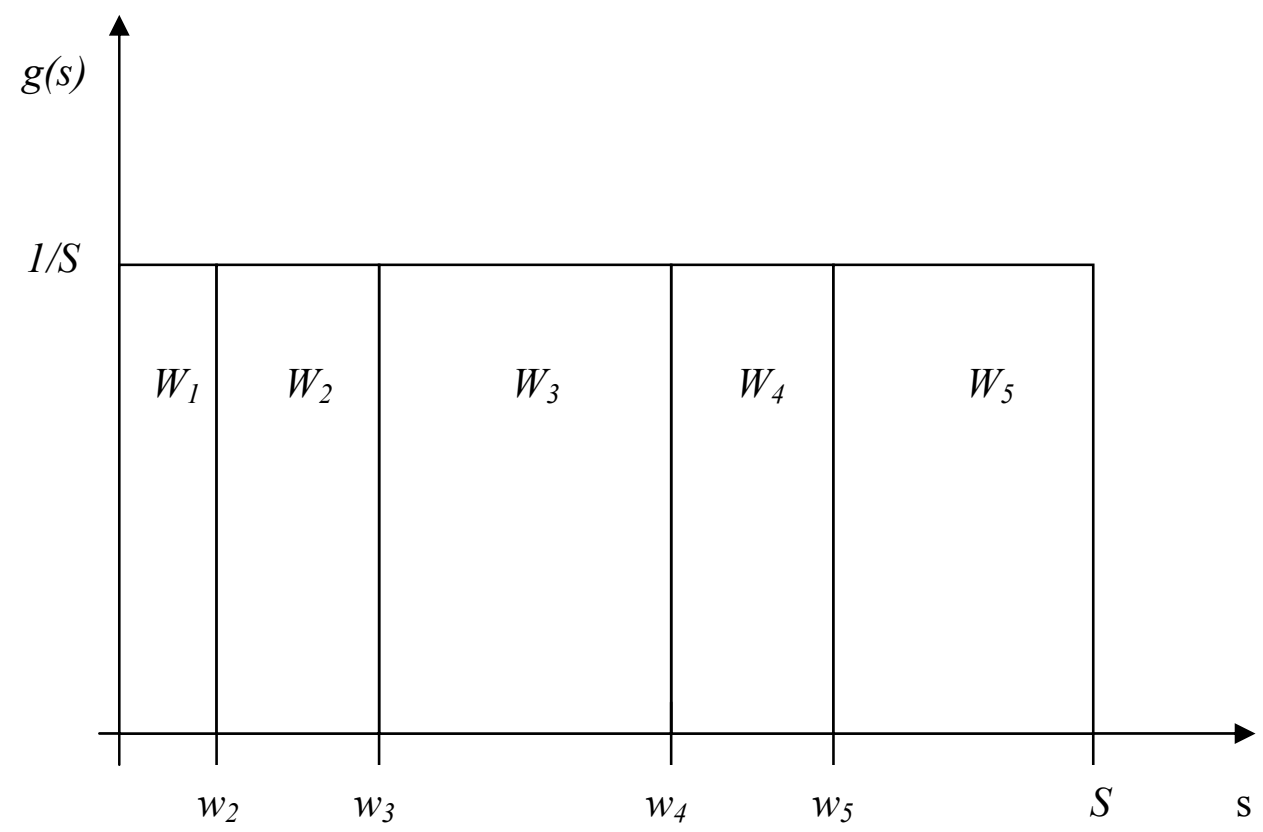


Figure 5. Within-Market Variation in Average Costs (Claims per Person)

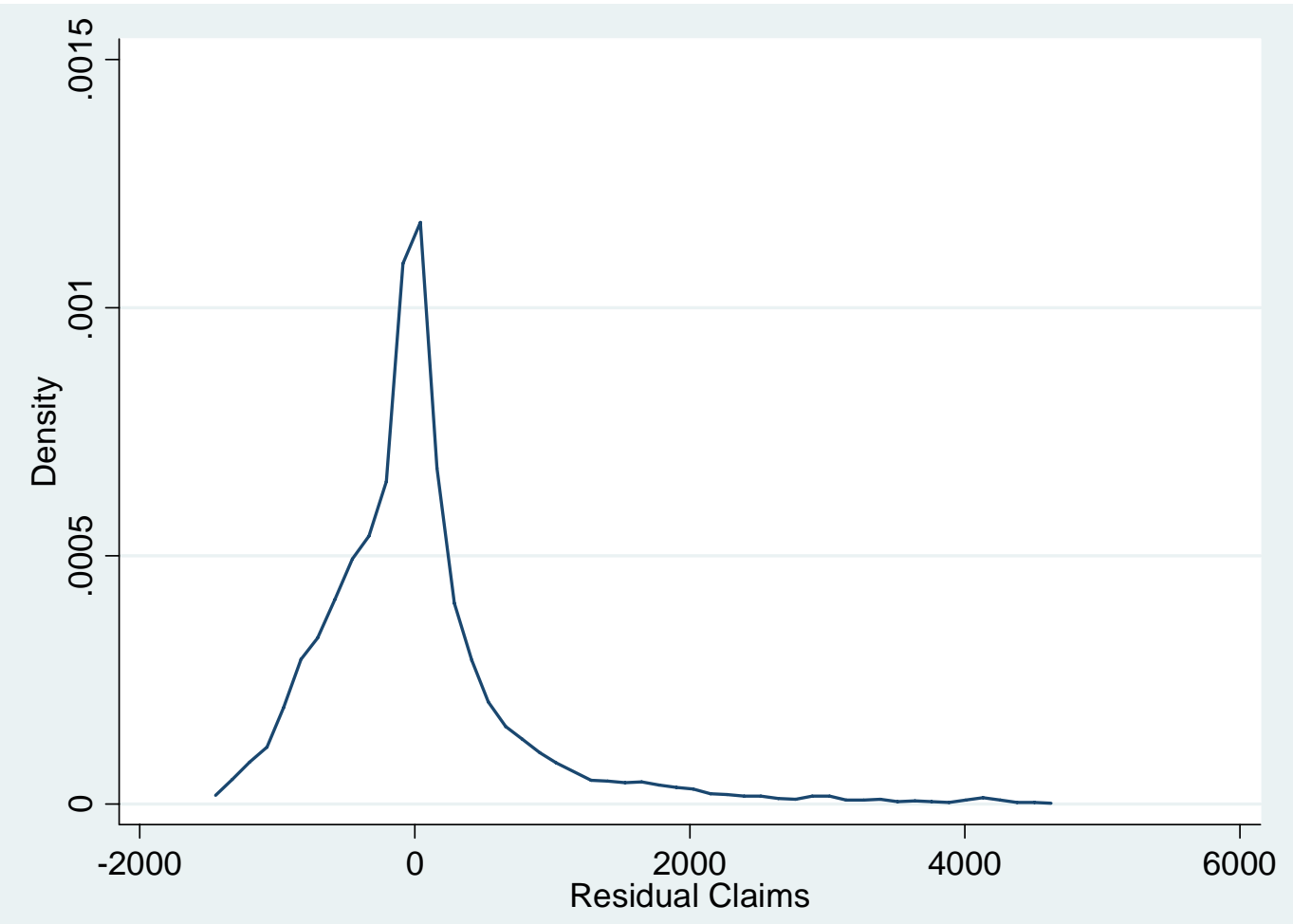

Notes: Data are from National Association of Insurance Commissioners, 2004. Density is for residuals from covered-lives weighted regression of claims per person on policy-state fixed effects. Shown are the 1st-99th percentiles. 
Figure 6. Within-Market Variation in Policy Loss Ratio for Attained Age Plans

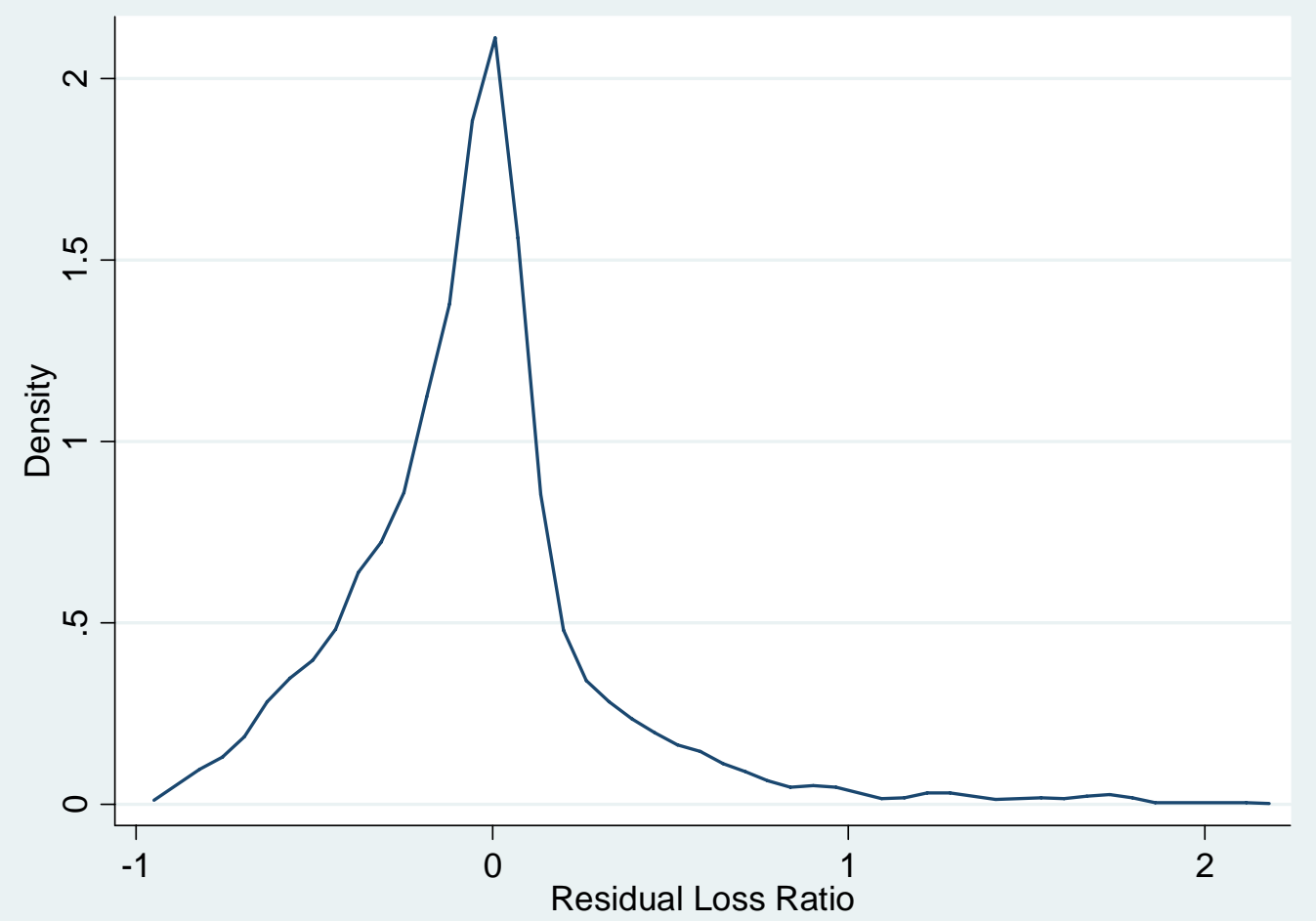

Notes: Data are from National Association of Insurance Commissioners, 2004. Density is for residuals from covered-lives weighted regression of loss-ratio on policy-state fixed effects. Shown are the 1st-99th percentiles. 
Table 1: Standardized Medigap Plan Benefits

\section{Plan Letter}

\begin{tabular}{l|l|l|l|l|l|l|l|l|l} 
A & B & C & D & E & F & G & H & I & J
\end{tabular}

Basic Benefits

Medicare Part A Coinsurance and Hospital Benefits

Medicare Part B Coinsurance or Copayment

Blood (three pints per year)

Extra Benefits

Skilled Nursing Facility Coinsurance

Medicare Part A Deductible

Medicare Part B Deductible

Medicare Part B Excess Charges

Foreign Travel Emergency

At-Home Recovery

Prescription Drugs ${ }^{2}$

Medicare-Covered Preventive Services

Notes:

We do not include two new plans introduced in 2005 (Plans K and L) since our analysis focuses on 2004.

${ }^{1}$ With plan G, 20 percent of Excess Charges must be paid by the policyholder.

${ }^{2}$ In 2006, Prescription Drug coverage was moved to the new Medicare prescription drug plans.

Source: Centers for Medicare and Medicaid Services, 2006a.

(all plans must cover)

\begin{tabular}{|c|c|c|c|c|c|c|c|c|}
\hline & $x$ & $x$ & $x$ & $x$ & $x$ & $x$ & $x$ & $x$ \\
\hline$x$ & $x$ & $x$ & $x$ & $x$ & $x$ & $x$ & $x$ & $x$ \\
\hline & $x$ & & & $\mathrm{X}$ & & & & $x$ \\
\hline & & & & $x$ & $\mathbf{x}^{1}$ & & $x$ & $x$ \\
\hline & $x$ & $x$ & $x$ & $X$ & $x$ & $x$ & $x$ & $x$ \\
\hline & & $x$ & & & $x$ & & $x$ & $x$ \\
\hline & & & & & & $x$ & $x$ & $x$ \\
\hline & & & $x$ & & & & & $x$ \\
\hline
\end{tabular}


Table 2. Summary Statistics for Merged Sample and NAIC Universe

Merged

Weiss-NAIC Sample

NAIC Universe

Total Covered Lives

$1,283,726$

$1,411,549$

A. Firms

Number of Firms

72

108

Number of Firms per State

4.5

4.4

Median Total Covered Lives

5,203

1,313

Median Total Premiums

$\$ 6,858,372$

$\$ 1,755,889$

Median Total Claims

$\$ 4,647,821$

$\$ 1,600,293$

Loss Ratio

0.686

0.714

Loss Ratio > 1.00

0.014

0.037

Loss Ratio < 0.65

0.375

0.315

Weiss Safety Rating A

0.208

Weiss Safety Rating $B$

0.347

Weiss Safety Rating C

0.250

0.167

Weiss Safety Rating D

0.028

0.666

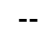

No Weiss Safety Rating

0.181

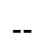

Operates in < 23 States

0.153

Operates in 23 to 36 States

0.102

\section{B. Policies}

Plan $A^{1}$

0.034

0.032

Plan $\mathrm{C}^{1}$

0.145

0.134

Plan $\mathrm{F}^{1}$

0.477

0.456

Attained $\mathrm{Age}^{1}$

0.447

Issue $\mathrm{Age}^{1}$

Community Rated ${ }^{1}$

0.211

0.341

0.722

0.658

Agent Solicited Policy

0.295

0.322

Direct Solicited Policy

91.8

100.3

Average Months Policy on Market

0.727

0.736

Loss Ratio > 1

0.116

0.077

Loss Ratio $<0.65$

0.533

0.346

Notes:

${ }^{1}$ Quantity-weighted by covered lives. See Appendix for merge details. Covered lives, premiums and claims are shown here as three-year totals over the period 2001-2004, as reported by NAIC.

Source: Authors' calculations using Weiss data, 2004, and NAIC data, 2004. 
Table 3. Premiums for Plan F Attained Age in Durham, NC 27708

\begin{tabular}{|c|c|c|}
\hline Company & $\begin{array}{l}\text { Annual } \\
\text { Premium }\end{array}$ & $\begin{array}{c}\text { Weiss } \\
\text { Safety Rating }\end{array}$ \\
\hline UNITED TEACHER ASSOCIATES INS CO & $\$ 1,145$ & $\mathrm{C}+$ \\
\hline UNICARE LIFE \& HEALTH INS CO & $\$ 1,164$ & B \\
\hline GLOBE LIFE \& ACCIDENT INS CO & $\$ 1,165$ & $\mathrm{~B}+$ \\
\hline PENNSYLVANIA LIFE INS CO & $\$ 1,273$ & C- \\
\hline PHYSICIANS LIFE INS CO & $\$ 1,322$ & A- \\
\hline CENTRAL RESERVE LIFE INS CO & $\$ 1,324$ & C- \\
\hline PACIFICARE LIFE \& HEALTH INS CO & $\$ 1,356$ & C- \\
\hline AMERICAN PIONEER LIFE INS CO & $\$ 1,356$ & B- \\
\hline MUTUAL OF OMAHA INSURANCE CO & $\$ 1,363$ & A- \\
\hline CONSECO HEALTH INS CO & $\$ 1,411$ & $\mathrm{D}+$ \\
\hline PYRAMID LIFE INS CO & $\$ 1,419$ & C \\
\hline BANKERS LIFE \& CASUALTY CO & $\$ 1,420$ & $\mathrm{D}+$ \\
\hline LINCOLN HERITAGE LIFE INS CO & $\$ 1,422$ & C+ \\
\hline STATE FARM MUTUAL AUTOMOBILE INS CO & $\$ 1,510$ & $\mathrm{~B}+$ \\
\hline AMERICAN REPUBLIC INS CO & $\$ 1,510$ & A- \\
\hline CONTINENTAL GENERAL INS CO & $\$ 1,511$ & C- \\
\hline CONTINENTAL LIFE INS OF BRENTWOOD & $\$ 1,534$ & B- \\
\hline CONSTITUTION LIFE INS CO & $\$ 1,679$ & $\mathrm{D}$ \\
\hline CENTRAL STATES HEALTH \& LIFE OF OMAHA & $\$ 1,689$ & $\mathrm{C}$ \\
\hline STERLING LIFE INS CO & $\$ 1,729$ & C- \\
\hline GE LIFE \& ANNUITY ASR CO & $\$ 1,751$ & B \\
\hline USAA LIFE INSURANCE COMPANY & $\$ 1,812$ & A \\
\hline WORLD INS COMPANY & $\$ 1,875$ & $B$ \\
\hline STANDARD LIFE \& ACCIDENT INS CO & $\$ 1,981$ & $\mathrm{~B}+$ \\
\hline MEDICO LIFE INS CO & $\$ 2,033$ & $\mathrm{D}+$ \\
\hline GUARANTEE TRUST LIFE INS CO & $\$ 2,055$ & C \\
\hline OXFORD LIFE INS CO & $\$ 2,311$ & C- \\
\hline \multicolumn{3}{|l|}{ Statistics } \\
\hline$\overline{\text { Number of Firms in Local Market }}$ & 27 & \\
\hline Mean Premium & $\$ 1,560$ & \\
\hline Standard Deviation & $\$ 301$ & \\
\hline Coefficient of Variation & 0.19 & \\
\hline
\end{tabular}

Notes: Data are from Weiss Ratings, Inc. for zip code 27708 in year 2004. Premiums are for 65year-old female nonsmokers, Plan F, attained age-rated. 
Table 4. Distribution of Within-Firm Price CVs over Zip Codes within a State

\begin{tabular}{|c|c|c|c|c|c|c|}
\hline \multirow[b]{2}{*}{ State } & \multirow{2}{*}{$\begin{array}{l}\text { Number } \\
\text { Policies }\end{array}$} & \multicolumn{3}{|c|}{ Within-in Firm CV } & \multirow{2}{*}{$\begin{array}{c}\text { Fraction } \\
\text { Same Rank } \\
\text { State and Zip }\end{array}$} & \multirow{2}{*}{$\begin{array}{c}\text { "Good" } \\
\text { State }\end{array}$} \\
\hline & & P50 & P75 & Max & & \\
\hline AK & 82 & 0.00 & 0.00 & 0.03 & 1.00 & 1 \\
\hline $\mathrm{AL}$ & 148 & 0.04 & 0.05 & 0.10 & 0.68 & 0 \\
\hline AR & 190 & 0.00 & 0.05 & 0.13 & 0.64 & 0 \\
\hline$A Z$ & 213 & 0.04 & 0.07 & 0.11 & 0.51 & 0 \\
\hline $\mathrm{CA}$ & 153 & 0.11 & 0.15 & 0.27 & 0.49 & 0 \\
\hline $\mathrm{CO}$ & 191 & 0.04 & 0.06 & 0.12 & 0.49 & 0 \\
\hline $\mathrm{CT}$ & 73 & 0.00 & 0.00 & 0.00 & 1.00 & 1 \\
\hline DC & 38 & 0.00 & 0.00 & 0.00 & 1.00 & 1 \\
\hline $\mathrm{DE}$ & 116 & 0.00 & 0.00 & 0.05 & 0.90 & 1 \\
\hline $\mathrm{FL}$ & 137 & 0.14 & 0.16 & 0.26 & 0.38 & 0 \\
\hline $\mathrm{GA}$ & 178 & 0.05 & 0.06 & 0.18 & 0.40 & 0 \\
\hline $\mathrm{HI}$ & 57 & 0.00 & 0.00 & 0.00 & 1.00 & 1 \\
\hline $\mathrm{IA}$ & 226 & 0.00 & 0.04 & 0.09 & 0.55 & 1 \\
\hline ID & 166 & 0.00 & 0.00 & 0.00 & 1.00 & 1 \\
\hline $\mathrm{IL}$ & 253 & 0.07 & 0.10 & 0.18 & 0.44 & 0 \\
\hline IN & 213 & 0.04 & 0.06 & 0.16 & 0.53 & 0 \\
\hline $\mathrm{KS}$ & 190 & 0.00 & 0.04 & 0.13 & 0.56 & 0 \\
\hline $\mathrm{KY}$ & 207 & 0.03 & 0.05 & 0.12 & 0.53 & 0 \\
\hline LA & 211 & 0.07 & 0.10 & 0.19 & 0.39 & 0 \\
\hline $\mathrm{MD}$ & 124 & 0.00 & 0.00 & 0.05 & 0.96 & 1 \\
\hline $\mathrm{ME}$ & 86 & 0.00 & 0.00 & 0.06 & 0.81 & 1 \\
\hline $\mathrm{MI}$ & 195 & 0.13 & 0.14 & 0.22 & 0.49 & 0 \\
\hline $\mathrm{MO}$ & 209 & 0.04 & 0.07 & 0.16 & 0.43 & 0 \\
\hline MS & 192 & 0.04 & 0.07 & 0.10 & 0.53 & 1 \\
\hline MT & 168 & 0.00 & 0.00 & 0.05 & 0.98 & 1 \\
\hline $\mathrm{NC}$ & 184 & 0.00 & 0.03 & 0.05 & 0.79 & 1 \\
\hline ND & 176 & 0.00 & 0.00 & 0.07 & 0.88 & 1 \\
\hline $\mathrm{NE}$ & 210 & 0.03 & 0.05 & 0.09 & 0.71 & 1 \\
\hline $\mathrm{NH}$ & 72 & 0.00 & 0.00 & 0.06 & 0.99 & 1 \\
\hline $\mathrm{NJ}$ & 48 & 0.00 & 0.00 & 0.00 & 1.00 & 1 \\
\hline NM & 160 & 0.00 & 0.04 & 0.09 & 0.66 & 1 \\
\hline NV & 153 & 0.06 & 0.10 & 0.16 & 0.45 & 0 \\
\hline$N Y$ & 52 & 0.05 & 0.10 & 0.16 & 0.65 & 0 \\
\hline $\mathrm{OH}$ & 248 & 0.05 & 0.07 & 0.19 & 0.45 & 0 \\
\hline OK & 241 & 0.03 & 0.06 & 0.12 & 0.52 & 0 \\
\hline OR & 159 & 0.00 & 0.00 & 0.12 & 0.74 & 0 \\
\hline PA & 182 & 0.08 & 0.11 & 0.17 & 0.43 & 0 \\
\hline $\mathrm{RI}$ & 76 & 0.00 & 0.00 & 0.00 & 1.00 & 1 \\
\hline $\mathrm{SC}$ & 194 & 0.03 & 0.06 & 0.12 & 0.59 & 0 \\
\hline SD & 188 & 0.00 & 0.00 & 0.04 & 0.94 & 1 \\
\hline $\mathrm{TN}$ & 243 & 0.04 & 0.06 & 0.12 & 0.50 & 0 \\
\hline $\mathrm{TX}$ & 260 & 0.08 & 0.10 & 0.21 & 0.39 & 0 \\
\hline UT & 105 & 0.00 & 0.00 & 0.04 & 0.95 & 1 \\
\hline VA & 191 & 0.04 & 0.11 & 0.19 & 0.40 & 0 \\
\hline VT & 39 & 0.00 & 0.00 & 0.00 & 1.00 & 1 \\
\hline WA & 107 & 0.00 & 0.00 & 0.00 & 0.79 & 1 \\
\hline WV & 176 & 0.00 & 0.04 & 0.10 & 0.71 & 1 \\
\hline WY & 151 & 0.00 & 0.00 & 0.04 & 0.84 & 1 \\
\hline
\end{tabular}

Notes: Unit of observation is firm-policy-state, where $\mathrm{CV}$ is coefficient of variation of premiums for a given policy by a given firm over all zip codes within a state. "Good" states are states are firms where the maximum CV in a state is less than 0.10 
Table 5. Coefficients of Variation of Premiums by State, Top 10 Policies

\begin{tabular}{|c|c|c|c|c|c|c|c|c|c|c|}
\hline & $\begin{array}{c}\text { F AA } \\
1\end{array}$ & $\begin{array}{c}\mathrm{F} \mathrm{CR} \\
2\end{array}$ & $\begin{array}{c}\mathrm{F} \mathrm{AA}^{*} \\
3\end{array}$ & $\begin{array}{c}\text { F IA } \\
4\end{array}$ & $\begin{array}{c}\mathrm{C} \mathrm{CR}^{*} \\
5\end{array}$ & $\begin{array}{c}\text { G AA } \\
6\end{array}$ & J CR & $\begin{array}{c}\text { D AA } \\
8\end{array}$ & $\begin{array}{c}\text { C AA } \\
9\end{array}$ & $\mathrm{C} \mathrm{IA}_{10}^{*}$ \\
\hline AK & 0.33 & & & 0.18 & & 0.09 & & 0.33 & 0.33 & \\
\hline$A L$ & 0.28 & & & 0.13 & & 0.23 & & 0.23 & 0.22 & \\
\hline AR & & & & & & & 0.48 & & & \\
\hline$A Z$ & 0.20 & & & 0.38 & & 0.18 & & 0.22 & 0.21 & \\
\hline CA & 0.35 & & & 0.08 & & 0.29 & & 0.13 & 0.37 & \\
\hline $\mathrm{CO}$ & 0.20 & & & 0.21 & & 0.18 & & 0.26 & 0.18 & \\
\hline CT & & 0.19 & & & 0.30 & & 0.09 & & & \\
\hline DC & 0.25 & & & & & & & & 0.22 & \\
\hline $\mathrm{DE}$ & 0.15 & & & 0.09 & & 0.08 & & 0.15 & 0.16 & \\
\hline $\mathrm{FL}$ & & & & 0.23 & & & & & & 0.22 \\
\hline GA & & & & 0.16 & & & & & & \\
\hline $\mathrm{HI}$ & 0.16 & & & 0.13 & & 0.11 & & 0.25 & 0.31 & \\
\hline IA & 0.24 & & & 0.19 & & 0.28 & & 0.26 & 0.20 & \\
\hline ID & & & & 0.24 & & & & & & \\
\hline IL & 0.25 & & 0.07 & 0.17 & & 0.19 & & 0.22 & 0.24 & \\
\hline IN & 0.24 & & & 0.25 & & 0.20 & & 0.24 & 0.24 & \\
\hline KS & 0.17 & & & 0.21 & & 0.19 & & 0.15 & 0.17 & \\
\hline KY & 0.19 & & & 0.18 & & 0.17 & & 0.23 & 0.18 & \\
\hline LA & 0.20 & & & 0.20 & & 0.15 & & 0.16 & 0.19 & \\
\hline MD & 0.15 & & & 0.17 & & 0.09 & & 0.12 & 0.15 & \\
\hline \multicolumn{11}{|l|}{ ME } \\
\hline MI & 0.25 & & & 0.22 & 0.13 & 0.20 & & 0.27 & 0.27 & \\
\hline MO & & & & 0.23 & & & & & & 0.09 \\
\hline MS & & & & & & 0.27 & & 0.20 & 0.23 & \\
\hline MT & 0.21 & & & 0.13 & & 0.19 & & 0.21 & 0.22 & \\
\hline NC & 0.18 & & & 0.18 & & 0.18 & & 0.21 & 0.18 & \\
\hline ND & & & & & & 0.21 & & 0.21 & 0.20 & \\
\hline $\mathrm{NE}$ & 0.24 & & & 0.16 & & 0.25 & & 0.24 & 0.21 & \\
\hline $\mathrm{NH}$ & & & & & & 0.12 & & 0.00 & 0.21 & \\
\hline $\mathrm{NJ}$ & 0.12 & & 0.04 & & & 0.20 & & 0.11 & 0.11 & \\
\hline NM & 0.25 & & & 0.27 & & 0.16 & & 0.19 & 0.23 & \\
\hline NV & 0.32 & & & 0.16 & & 0.25 & & 0.32 & 0.32 & \\
\hline \multicolumn{11}{|l|}{ NY } \\
\hline $\mathrm{OH}$ & 0.48 & & & 0.27 & & 0.28 & & 0.21 & 0.44 & \\
\hline OK & 0.24 & & & 0.34 & & 0.21 & & 0.23 & 0.20 & \\
\hline OR & 0.22 & & & 0.22 & & 0.24 & & 0.27 & 0.23 & \\
\hline PA & 0.21 & & & & & 0.16 & & 0.23 & 0.18 & \\
\hline RI & 0.23 & & & 0.16 & & 0.20 & & 0.20 & 0.16 & \\
\hline SC & 0.27 & & & 0.24 & & 0.22 & & 0.27 & 0.26 & \\
\hline SD & 0.27 & & & 0.15 & & 0.31 & & 0.24 & 0.26 & \\
\hline $\mathrm{TN}$ & 0.23 & & & 0.19 & & 0.24 & & 0.24 & 0.25 & \\
\hline TX & 0.21 & & & 0.35 & & 0.23 & & 0.22 & 0.19 & \\
\hline UT & 0.20 & & & 0.26 & & 0.18 & & 0.17 & 0.16 & \\
\hline VA & 0.24 & & & 0.19 & & 0.16 & & 0.21 & 0.20 & \\
\hline \multicolumn{11}{|l|}{ VT } \\
\hline WA & & 0.07 & & & 0.01 & & & & & \\
\hline WV & 0.27 & & & 0.06 & & 0.20 & & 0.22 & 0.23 & \\
\hline$W Y$ & 0.23 & & & 0.27 & & 0.19 & & 0.27 & 0.21 & \\
\hline
\end{tabular}


Table 6. Tobit Estimation of Demand Equation (4')

\begin{tabular}{|c|c|c|c|}
\hline & \multirow{2}{*}{$\begin{array}{c}\text { Tobit } \\
\text { Demand Eq. }\end{array}$} & \multicolumn{2}{|c|}{ IV Tobit } \\
\hline & & Demand Eq. & Price Eq. \\
\hline Premium in 2004 & $\begin{array}{l}-0.002^{\star \star} \\
(0.000)\end{array}$ & $\begin{array}{l}-0.007^{* *} \\
(0.001)\end{array}$ & -- \\
\hline Premium in 2001 & -- & -- & $\begin{array}{l}0.864^{\star \star} \\
(0.032)\end{array}$ \\
\hline Firm Weiss Safety Rating A & $\begin{array}{l}0.356 \\
(0.294)\end{array}$ & $\begin{array}{l}2.410 * \star \\
(0.446)\end{array}$ & $\begin{array}{l}182.763^{\star \star} \\
(28.246)\end{array}$ \\
\hline Firm Weiss Safety Rating B & $\begin{array}{l}0.805^{\star \star} \\
(0.226)\end{array}$ & $\begin{array}{l}1.107^{\star \star} \\
(0.299)\end{array}$ & $\begin{array}{l}63.187^{\star *} \\
(19.185)\end{array}$ \\
\hline Firm Weiss Safety Rating C & $\begin{array}{l}0.208 \\
(0.202)\end{array}$ & $\begin{array}{l}0.287 \\
(0.279)\end{array}$ & $\begin{array}{l}100.946 \text { ** } \\
(17.566)\end{array}$ \\
\hline No Weiss Safety Rating for Firm & $\begin{array}{l}0.868 \\
(0.852)\end{array}$ & $\begin{array}{l}-0.016 \\
(1.107)\end{array}$ & $\begin{array}{l}-65.001 \\
(74.560)\end{array}$ \\
\hline Firm Operates in $>36$ States & $\begin{array}{l}-0.030 \\
(0.223)\end{array}$ & $\begin{array}{l}0.895^{\star \star} \\
(0.286)\end{array}$ & $\begin{array}{l}103.801^{\star \star} \\
(18.469)\end{array}$ \\
\hline Firm Operates in 23 to 36 States & $\begin{array}{l}-0.690 * \star \\
(0.220)\end{array}$ & $\begin{array}{l}0.953^{\star \star} \\
(0.334)\end{array}$ & $\begin{array}{l}282.160 \star \star \\
(18.899)\end{array}$ \\
\hline Number of Policies Offered by Firm & $\begin{array}{l}-0.078^{\star} \\
(0.037)\end{array}$ & $\begin{array}{l}0.016 \\
(0.047)\end{array}$ & $\begin{array}{l}-1.882 \\
(3.054)\end{array}$ \\
\hline Agent Solicited Policy & $\begin{array}{l}1.445^{\star \star} \\
(0.249)\end{array}$ & $\begin{array}{l}3.169 \star \star \\
(0.329)\end{array}$ & $\begin{array}{l}140.809 * * \\
(20.310)\end{array}$ \\
\hline Stale Price & $\begin{array}{l}-0.050 \\
(0.334)\end{array}$ & $\begin{array}{l}-1.093^{\star \star} \\
(0.419)\end{array}$ & $\begin{array}{l}-237.886^{\star *} \\
(26.857)\end{array}$ \\
\hline Policy on Market < 48 Months & $\begin{array}{l}-0.578^{\star \star} \\
(0.202)\end{array}$ & $\begin{array}{l}-1.220 \star \star \\
(0.348)\end{array}$ & $\begin{array}{l}-118.327^{\star *} \\
(22.179)\end{array}$ \\
\hline Policy on Market 48 to 72 Months & $\begin{array}{l}-0.541^{\star \star} \\
(0.208)\end{array}$ & $\begin{array}{l}-0.945^{\star \star} \\
(0.258)\end{array}$ & $\begin{array}{l}-10.891 \\
(16.966)\end{array}$ \\
\hline Policy Loss Ratio <0.65 & $\begin{array}{l}-2.170 \star \star \\
(0.158)\end{array}$ & $\begin{array}{l}-2.185^{\star \star} \\
(0.212)\end{array}$ & $\begin{array}{l}11.732 \\
(14.655)\end{array}$ \\
\hline Policy Loss Ratio >1 & $\begin{array}{l}-2.241^{\star \star} \\
(0.241)\end{array}$ & $\begin{array}{l}-1.901^{\star \star} \\
(0.313)\end{array}$ & $\begin{array}{l}28.366 \\
(21.262)\end{array}$ \\
\hline Firm Loss Ratio CV over Policies & $\begin{array}{l}-0.442^{\star \star} \\
(0.137)\end{array}$ & $\begin{array}{l}-0.498^{\star *} \\
(0.189)\end{array}$ & $\begin{array}{l}25.387^{\star} \\
(11.823)\end{array}$ \\
\hline Firm Price CV over Zip Codes & $\begin{array}{l}-10.727^{\star \star} \\
(2.069)\end{array}$ & $\begin{array}{l}-10.199 * * \\
(2.757)\end{array}$ & $\begin{array}{l}534.339 \star \star \\
(177.943)\end{array}$ \\
\hline Missing Duration & $\begin{array}{l}-2.543^{\star \star} \\
(0.285)\end{array}$ & $\begin{array}{l}-1.522^{\star \star} \\
(0.367)\end{array}$ & $\begin{array}{l}142.628^{\star \star} \\
(23.036)\end{array}$ \\
\hline Missing Loss Ratio & $\begin{array}{l}-8.334^{\star \star} \\
(0.374)\end{array}$ & $\begin{array}{l}-7.975^{\star \star} \\
(0.509)\end{array}$ & $\begin{array}{l}130.368^{\star *} \\
(16.673)\end{array}$ \\
\hline Constant & $\begin{array}{l}0.260 \\
(0.136)\end{array}$ & $\begin{array}{l}0.795^{\star \star} \\
(0.186)\end{array}$ & $\begin{array}{l}127.480^{\star *} \\
(11.391)\end{array}$ \\
\hline Observations & 3385 & & 331 \\
\hline
\end{tabular}

Notes: *, **: significant at 5 and 1 percent levels, respectively. All regressors entered in deviations from market-level mean, where markets are policy-state combinations. Reference group for Weiss Safety Rating is Category D; for states of operation is fewer than 23 states; and for policy market duration greater than 72 months. Stale prices are prices with effective date preceding 2003. Standard errors in parentheses. Data are from Weiss Ratings, 2004 and NAIC, 2004. 
Table 7. Alternative Specifications of Demand Equation (4')

\begin{tabular}{|c|c|c|c|c|c|}
\hline & $\begin{array}{l}\text { OLS } \\
(1)\end{array}$ & $\begin{array}{l}\text { Tobit } \\
\text { (2) }\end{array}$ & $\begin{array}{c}\text { IV Tobit, } \\
\text { No Controls } \\
\text { (3) }\end{array}$ & $\begin{array}{c}\text { IV Tobit, } \\
\text { "Good" States } \\
\text { (4) }\end{array}$ & $\begin{array}{c}\text { IV Tobit, } \\
\text { (Table 6) } \\
(5)\end{array}$ \\
\hline Premium in 2004 & $\begin{array}{c}-0.002^{* *} \\
(0.000)\end{array}$ & $\begin{array}{c}-0.002^{\star *} \\
(0.000)\end{array}$ & $\begin{array}{c}-0.009^{\star *} \\
(0.001)\end{array}$ & $\begin{array}{c}-0.007^{\star *} \\
(0.001)\end{array}$ & $\begin{array}{c}-0.007^{\star *} \\
(0.001)\end{array}$ \\
\hline Observations & 2331 & 2331 & 2331 & 839 & 2331 \\
\hline
\end{tabular}

Notes: * **: significant at 5 and 1 percent levels, respectively. All columns except (3) based on same specification as in Table 6. Standard errors in parentheses. Column (4) has no covariates other than price (instrumented). In column (5), "Good" states are states in which the maximum within-firm CV over all zip codes is <0.10. Data are from Weiss Ratings, 2004 and NAIC, 2004. 


\section{Appendix 1: Formulas}

\section{A.1.a. Demand Equation}

$$
q_{j}=\frac{Q}{N}\left[1-\frac{1}{S}\left(\bar{u}-u_{j}\right)\right]
$$

First, we use equation (2),

$$
w_{k}=\sum_{i=1}^{k-1} \frac{1}{N}\left(u_{i}-u_{k}\right)=\frac{1}{N} \sum_{i=1}^{k-1} u_{i}-\frac{k-1}{N} u_{k}
$$

and substitute the $w_{k}$ 's in equation (3'):

$$
q_{j}=\frac{Q}{N}-\frac{Q}{j} \frac{w_{j}}{S}+\sum_{k=j+1}^{N}\left[\frac{Q}{k(k-1)} \frac{w_{k}}{S}\right]
$$

Then the following terms within this equation are obtained:

$$
\begin{aligned}
\frac{Q}{j} \frac{w_{j}}{S} & =\frac{Q}{j S}\left[\frac{1}{N} \sum_{i=1}^{j-1} u_{i}-\frac{j-1}{N} u_{j}\right] \\
& =\frac{1}{S} \frac{Q}{N}\left[\frac{1}{j} \sum_{i=1}^{j-1} u_{i}-\frac{j-1}{j} u_{j}\right]
\end{aligned}
$$

and

$$
\begin{aligned}
\sum_{k=j+1}^{N}\left[\frac{Q}{k(k-1)} \frac{w_{k}}{S}\right] & =\frac{1}{S} \sum_{k=j+1}^{N}\left[\frac{Q}{k(k-1)}\left(\frac{1}{N} \sum_{i=1}^{k-1} u_{i}-\frac{k-1}{N} u_{k}\right)\right] \\
& =\frac{1}{S} \frac{Q}{N} \sum_{k=j+1}^{N}\left[\frac{1}{k(k-1)}\left(\sum_{i=1}^{k-1} u_{i}-(k-1) u_{k}\right)\right]
\end{aligned}
$$

To obtain equation (4), we use (10) and (11) and evaluate for each $q_{j}$, starting with $q_{N}$ :

$$
\begin{aligned}
q_{N} & =\frac{Q}{N} \frac{1}{S}\left[S-\left(\frac{1}{N}\left(u_{1}+u_{2}+\ldots+u_{N-1}\right)-\frac{(N-1)}{N} u_{N}\right)+0\right] \\
& =\frac{Q}{N} \frac{1}{S}\left[S-\left(\frac{1}{N}\left(\sum_{i=1}^{N} u_{i}-u_{N}\right)-\frac{(N-1)}{N} u_{N}\right)\right] \\
& =\frac{Q}{N} \frac{1}{S}\left[S-\left(\bar{u}_{N}-u_{N}\right)\right]=\frac{Q}{N}\left[1-\frac{1}{S}\left(\bar{u}-u_{N}\right)\right]
\end{aligned}
$$


For $q_{N-1}$ we get:

$$
\begin{aligned}
q_{N-1} & =\frac{Q}{N} \frac{1}{S}\left[S-\left(\frac{1}{N-1}\left(u_{1}+\ldots+u_{N-2}\right)-\frac{N-2}{N-1} u_{N-1}\right)\right. \\
& \left.+\left(\frac{1}{N(N-1)}\right)\left[\left(u_{1}+\ldots+u_{N-1}\right)-(N-1) u_{N}\right]\right] \\
& =\frac{Q}{N} \frac{1}{S}\left[S-\left(\frac{1}{N-1}\left(\sum_{i=1}^{N} u_{i}-u_{N-1}-u_{N}\right)-\frac{N-2}{N-1} u_{N-1}\right)\right. \\
& \left.+\left(\frac{1}{N(N-1)}\right)\left[\sum_{i=1}^{N} u_{i}-u_{N}-(N-1) u_{N}\right]\right] \\
= & \frac{Q}{N} \frac{1}{S}\left[S-\frac{1}{N-1}\left(\sum_{i=1}^{N} u_{i}-u_{N-1}-u_{N}-(N-2) u_{N-1}-\frac{1}{N} \sum_{i=1}^{N} u_{i}+\frac{1}{N} u_{N}+\frac{N-1}{N} u_{N}\right)\right] \\
= & \frac{Q}{N} \frac{1}{S}\left[S-\frac{1}{N-1}\left(N \bar{u}-\bar{u}-(N-1) u_{N-1}-u_{N}+u_{N}\right)\right] \\
= & \frac{Q}{N} \frac{1}{S}\left[S-\left(\bar{u}-u_{N-1}\right)\right]=\frac{Q}{N}\left[1-\frac{1}{S}\left(\bar{u}-u_{N-1}\right)\right]
\end{aligned}
$$

Repeating this process for each firm $\mathrm{j}$ leads to the demand equation (4).

\section{A.1.b. Price Equation}

The price equation (9) follows from maximizing equation (8)

$$
\Pi_{j}=p_{j} q_{j}-c_{j}\left(q_{j}\right)
$$

with respect to price, after substituting in the cost equation, (7):

$$
c_{j}\left(q_{j}\right)=\alpha_{j} q_{j}+\beta q_{j}^{2}=\alpha_{j}\left\{\frac{Q}{N}\left[1-\frac{1}{S}\left(\bar{u}-u_{j}\right)\right]\right\}+\beta\left\{\frac{Q}{N}\left[1-\frac{1}{S}\left(\bar{u}-u_{j}\right)\right]\right\}^{2}
$$

Note that from equation (4) and equation (1),

$$
\frac{\partial q_{j}}{\partial p_{j}}=-\frac{Q(N-1)}{S N^{2}}
$$


Then we obtain the following derivative with respect to (the firm's own) price:

$$
\begin{aligned}
\frac{\partial \Pi_{j}}{\partial p_{j}}= & q_{j}+p_{j} \frac{\partial q_{j}}{\partial p_{j}}-\alpha_{j} \frac{\partial q_{j}}{\partial p_{j}}-2 \beta q_{j} \frac{\partial q_{j}}{\partial p_{j}} \\
= & \frac{Q}{N}+\frac{2 \beta Q}{N} \frac{Q(N-1)}{S N^{2}}+\alpha_{j} \frac{Q(N-1)}{S N^{2}}+\frac{Q}{S N^{2}} \sum_{i \neq j} p_{i}+\frac{2 \beta Q}{S N^{2}} \frac{Q(N-1)}{S N^{2}} \sum_{i \neq j} p_{i} \\
& -\frac{Q}{S N} \lambda\left(X_{j}-\bar{X}\right)-\frac{2 \beta Q}{S N} \frac{Q(N-1)}{S N^{2}} \lambda\left(X_{j}-\bar{X}\right) \\
& -\frac{Q}{S N} p_{j}+\frac{Q}{S N^{2}} p_{j}-\frac{Q(N-1)}{S N^{2}} p_{j}-\frac{2 \beta Q}{S N} \frac{Q(N-1)}{S N^{2}} p_{j}+\frac{2 \beta Q}{S N^{2}} \frac{Q(N-1)}{S N^{2}} p_{j} \equiv 0
\end{aligned}
$$

This can be simplified into the following expression:

$$
\begin{aligned}
& p_{j}[(2+\gamma)(N-1)]=(1+\gamma) N\left[S-\lambda\left(X_{j}-\bar{X}\right)\right]+\alpha_{j}(N-1)+(1+\gamma) \sum_{i \neq j} p_{i} \text { or } \\
& p_{j}=\frac{1+\gamma}{2+\gamma} \frac{1}{N-1} \sum_{i \neq j} p_{i}+\frac{1}{2+\gamma} \alpha_{j}+\frac{1+\gamma}{2+\gamma} \frac{N}{N-1} S-\frac{1+\gamma}{2+\gamma} \frac{N}{N-1} \lambda\left(\bar{X}-X_{j}\right), \text { where } \\
& \gamma=\frac{2 \beta Q(N-1)}{S N^{2}}
\end{aligned}
$$

Since the solution is algebraically complicated, we now show with an example of three firms, that the solution presented in equation (9) is correct. For $N=3$, there are three equations (16) in three unknowns, which can be solved by substituting in.

$$
\begin{aligned}
& p_{1}=\frac{1+\gamma}{2+\gamma} \frac{1}{N-1}\left(p_{2}+p_{3}\right)+\frac{1}{2+\gamma} \alpha_{1}+\frac{1+\gamma}{2+\gamma} \frac{N}{N-1} S-\frac{1+\gamma}{2+\gamma} \frac{N}{N-1} \lambda\left(\bar{X}-X_{1}\right) \\
& p_{2}=\frac{1+\gamma}{2+\gamma} \frac{1}{N-1}\left(p_{1}+p_{3}\right)+\frac{1}{2+\gamma} \alpha_{2}+\frac{1+\gamma}{2+\gamma} \frac{N}{N-1} S-\frac{1+\gamma}{2+\gamma} \frac{N}{N-1} \lambda\left(\bar{X}-X_{2}\right) \\
& p_{3}=\frac{1+\gamma}{2+\gamma} \frac{1}{N-1}\left(p_{1}+p_{2}\right)+\frac{1}{2+\gamma} \alpha_{3}+\frac{1+\gamma}{2+\gamma} \frac{N}{N-1} S-\frac{1+\gamma}{2+\gamma} \frac{N}{N-1} \lambda\left(\bar{X}-X_{3}\right)
\end{aligned}
$$

Substituting $\left(16_{3}\right)$ into $\left(16_{2}\right)$ and solving for $p_{2}$ yields a function in terms of $p_{1}$ :

$$
\begin{aligned}
p_{2}= & \frac{(1+\gamma)}{(3+\gamma)} p_{1}+\frac{(1+\gamma)}{(3+\gamma)} 3 S-\frac{(1+\gamma)(2+\gamma)}{(5+3 \gamma)(3+\gamma)} 6\left(\bar{X}-X_{2}\right)-\frac{(1+\gamma)^{2}}{(5+3 \gamma)(3+\gamma)} 3\left(\bar{X}-X_{3}\right) \\
& +\frac{4 \alpha_{2}(2+\gamma)}{(5+3 \gamma)(3+\gamma)}+\frac{2 \alpha_{3}(1+\gamma)}{(5+3 \gamma)(3+\gamma)}
\end{aligned}
$$


Plugging $\left(16_{2}^{\prime}\right)$ back into $\left(16_{3}\right)$ yields a similar formula for $p_{3}$ :

$$
\begin{aligned}
p_{3}= & \frac{(1+\gamma)}{(3+\gamma)} p_{1}+\frac{(1+\gamma)}{(3+\gamma)} 3 S-\frac{(1+\gamma)(2+\gamma)}{(5+3 \gamma)(3+\gamma)} 6\left(\bar{X}-X_{3}\right)-\frac{(1+\gamma)^{2}}{(5+3 \gamma)(3+\gamma)} 3\left(\bar{X}-X_{2}\right) \\
& +\frac{4 \alpha_{3}(2+\gamma)}{(5+3 \gamma)(3+\gamma)}+\frac{2 \alpha_{2}(1+\gamma)}{(5+3 \gamma)(3+\gamma)}
\end{aligned}
$$

Then, using $\left(16_{2}^{\prime}\right)$ and $\left(16_{3}{ }^{\prime}\right)$ in $\left(16_{1}\right)$, we obtain the formula for $p_{1}$ :

$$
\begin{aligned}
p_{1}= & \frac{3}{2} \frac{(1+\gamma)(5+3 \gamma)}{(5+3 \gamma)} S+\frac{1}{2} \frac{(2+2 \gamma)}{(5+3 \gamma)}\left(\alpha_{1}+\alpha_{2}+\alpha_{3}\right)+\frac{1}{2} \frac{2 \alpha_{1}}{(5+3 \gamma)} \\
& -\frac{1}{2} \frac{3(1+\gamma)^{2}}{(5+3 \gamma)}\left[\lambda\left(3 \bar{X}-X_{1}-X_{2}-X_{3}\right)\right]-\frac{1}{2} \frac{6(1+\gamma)}{(5+3 \gamma)} \lambda\left(\bar{X}-X_{1}\right)
\end{aligned}
$$

Note that $\left(3 \bar{X}-X_{1}-X_{2}-X_{3}\right)=0$; then after some rearranging of the $a_{1}$ terms, $\left(16_{1}{ }^{\prime}\right)$ simplifies

to:

(161") $p_{1}=\alpha_{1}+\frac{3}{2}(1+\gamma) S+\frac{(1+\gamma)}{(5+3 \gamma)} 3\left(\bar{\alpha}-\alpha_{1}\right)-\frac{(1+\gamma)}{(5+3 \gamma)} 3 \lambda\left(\bar{X}-X_{1}\right)$,

which is exactly what was proposed in equation (9) if $N=3$.

\section{A.1.c. Profit Maximization}

For firms to be profit maximizing, the second derivative has to be negative:

$$
\begin{aligned}
\frac{\partial^{2} \Pi_{j}}{\partial p_{j}^{2}} & =-\frac{Q}{S N}+\frac{Q}{S N^{2}}-\frac{Q(N-1)}{S N^{2}}-\frac{2 \beta Q}{S N} \frac{Q(N-1)}{S N^{2}}+\frac{2 \beta Q}{S N^{2}} \frac{Q(N-1)}{S N^{2}} \\
& =-\frac{2 Q(N-1)}{S N^{2}}\left[1+\frac{\beta Q(N-1)}{S N^{2}}\right]
\end{aligned}
$$

Note that (17) is only less than zero if

$$
1+\frac{\beta Q(N-1)}{S N^{2}}>0 \Rightarrow \beta>-\frac{S N^{2}}{Q(N-1)}
$$

Hence $\beta$ is bounded from below, where $\beta \geq 0$ will lead to the profit maximizing condition in any case. 


\section{Appendix 2: Data}

Our first dataset is a snapshot of Medigap premiums in effect 2004 by zip code from Weiss Ratings, Inc. It contains the premium charged for any plan letter offered by a firm, by age, plan type (i.e. standard, select, or smoker), rating method, and gender. We use the following algorithm to aggregate the data to the state level.

Within any zip code, no firm offers more than one plan within an age-plan letter-plan type-rating method cell. We restrict the data to standard plans (of all letters) for 65 year-olds only; hence we reduce the dimensionality to plan letter-rating method cells within every zip code. For each firm in each cell, we then average premiums over zip codes in the state.

Our second dataset, from NAIC, contains data for all Medigap policies issued by insurance companies in a given state during the years 2002-2004. We only keep observations on individual standard Medigap policies offered after OBRA-90 within the continental United States (except Massachusetts, Minnesota, and Wisconsin which have different standardization schemes). Some plan letters are offered more than once by the same firm in the same state. These are likely to be plans that differ across counties, as observed in the Weiss data. Since we have no means of identifying these local differences, we combine these plans (about 22 percent), summing up covered lives, premiums and claims, such that each firm only offers one policy in each state-plan letter cell.

Both the Weiss data and the NAIC data have the unique NAIC identification code and company name of the firms offering a Medigap policy. We merge the two datasets based on the NAIC identifier, the US state of operation and the plan letter. (Note that the NAIC data do not have any information on the age of the people covered under the policy.) In most state-plan letter combinations, the fraction not matched is very low; however in order to guarantee that we observe "most" of any given market, we drop those state-plan letter cells where the fraction not matched exceeds 50 percent. Overall, we drop cells representing just 5,618 covered lives, or 0.3 percent of total covered lives. Overall, the percent of covered lives represented by firms in the NAIC data that we successfully merge to firms in the Weiss data is 91 percent. 